\title{
Job loss by wage level: lessons from the Great Recession in Ireland
}

\author{
Brian Nolan ${ }^{1}$ and Sarah Voitchovsky ${ }^{2^{*}}$
}

\author{
* Correspondence: sarah \\ voitchovsky@unimelb.edu.au \\ ${ }^{2}$ Melbourne Institute of Applied \\ Economics of Social Research, \\ University of Melbourne, Level 5 \\ Business and Economics Building, \\ 111 Barry Street, Melbourne, Victoria \\ 3010, Australia \\ Full list of author information is \\ available at the end of the article
}

\begin{abstract}
This paper explores the incidence of job loss by wage level during the Great Recession, using data for Ireland. Ireland experienced a particularly pronounced decline in employment by international and historical standards, which makes it a valuable case study. Using EU Survey on Income and Living Conditions (EU-SILC) data, our analysis reveals that the probability that an employee remains in employment, from one year to the next, is positively related to their monthly earnings during both boom and bust. The gradient with wages, however, is much more marked during the bust and remains significantly so even after controlling for a range of individual characteristics including gender, age, education, labour market history, part-time status, industries or occupations.
\end{abstract}

JEL codes: E24, J23, J24, J62, J63

Keywords: Skills, Occupations, Wages, Great recession, Ireland, Job loss, EU-SILC

\section{Introduction}

The risk of losing one's job is a central aspect of economic security for the individual worker and his or her family and its perceived precariousness an important feature of the "quality" of a job. But who is actually at the greatest risk of losing their job in a deep recession, compared with a more benign economic environment? The longerterm hollowing-out of occupational structures driven by the combination of technology and trade has become a major focus for research, and concern about the "squeezed middle" is a prominent theme for politicians and commentators through the Great Recession and its aftermath. In that context, it is important to know whether recession accentuates such hollowing-out and has a major impact on the middle of the occupational and wage distribution or predominantly affects those who would traditionally have been seen as most at risk. Ireland's distinctive experience of boom and bust makes it a valuable case study of job loss, and the available data allows us to incorporate both individual and job characteristics into the analysis, including occupation and wage level, so that the incidence of job loss across the wage distribution can be identified and explored.

Ireland experienced a severe economic downturn in 2008, following years of rapid economic growth. The effects of the recession were magnified by a domestic banking crisis and the bursting of a domestic property bubble. Approximately $15 \%$ of all employment positions held in the first quarter of 2008 had disappeared by mid-2012,

\section{Springer}


according to Quarterly National Household Survey (QNHS) data. Reductions in earnings together with falling asset prices and increased tax burden affected most households. Real average equivalised disposable income fell by $13 \%$ between 2008 and 2013 (Savage et al. 2015). While the country's progressive tax and transfer system has been credited with mitigating the worst of the distributional impact of the crisis, real equivalised disposable household income at the bottom decile fell by $22 \%$ over that period (Savage et al. 2015). Changing labour market circumstances have been shown to account for most of the deteriorating economic situation of poorer households, see McGinnity et al. (2014), Mühlau (2014), and Savage et al. (2015). The aim of this study therefore is to get a better understanding of the dynamics of the labour market, and in particular, whether workers in specific parts of the wage distribution have been more affected than others.

Existing evidence reveals a number of labour market trends. In Ireland, as in other countries, younger workers, men and workers with less education have experienced a higher incidence of job loss (see, e.g. Autor 2010; Elsby et al. 2010 for the USA; McGinnity et al. 2014; Kelly and McGuinness 2015; Savage et al. 2015 for Ireland).

It is often argued that this demographic of workers tends to be concentrated in industries that are more sensitive to the business cycle. Labour market fluctuations by industry certainly played an important role in explaining the distribution of job loss in Ireland (e.g. McGinnity et al. 2014). The recession in Ireland coincided with the end of a property bubble. The construction sector, which employed about $20 \%$ of male workers in the first quarter of 2008, had lost $62 \%$ of its employment positions by the third quarter of 2012, according to QNHS data. Although the decline in jobs associated with specific industries may account for a large part of the gender differences in job loss, the trend was not systematic across industries. ${ }^{1}$ In some industries-such as the professional, scientific and technical activities or the financial, insurance and real estate activities-the rate of job loss has been higher for women than for men, on average. Also, in the wholesale and retail trade sector, which employed about $15 \%$ of all people at work in the first quarter of 2008 , divided almost equally between men and women, the timing of job loss varied significantly by gender. ${ }^{2}$

Another observation is that job loss has been particularly high in certain occupations. Assuming that differences in earnings between occupations reflect differences in labour market skills, then this shift can be interpreted as implying that certain skill groups have been more affected during the crisis. Several studies on US data have reported that workers in middle-wage/middle-skill occupations have been disproportionately hit during the crisis, leading to a polarisation of jobs on the labour market (Autor 2010; Foote and Ryan 2015). Although accentuated during the crisis, this occupational polarisation is reported to have started much earlier (Autor 2010). Similar trends in occupational polarisation have been described for a number of European countries before the crisis (Goos et al. 2009) and are usually interpreted in the context of skill-bias technological change arguments. In the case of European countries, however, evidence for polarisation appears somewhat sensitive to the ordering and/or grouping of occupations considered (e.g. Fernandez-Macias 2012).

The study of Mühlau (2014) for Ireland reveals that here was a slight increase in the number of people employed in the top occupations (managers, professionals, associate professionals and technicians) during the Great Recession. Similar trends are reported 
for the USA (Autor 2010). Workers in "skilled trades" and "process, plant and machine operatives" occupations, however, experienced some of the highest rates of job loss in Ireland, see Figure 1 in the Appendix. These jobs would appear towards the middle or towards the bottom of the skill distribution, depending on the occupation ranking considered (see Mühlau 2014). As discussed in Goldthorpe and McKnight (2004), even in boom years, employment conditions differ significantly across occupations. Workers in lower skill occupations typically experience less economic security (higher risk of dismissal), more income instability and lower prospects for future wage growth. ${ }^{3}$ The different contractual arrangements across occupations reflect in part the difficulty of "work monitoring" and the "human asset specificity" of employees in different jobs (Goldthorpe and McKnight 2004).

Provided that specific parts of the wage distribution have been more affected than others during the crisis, we would like to know how far these trends can be explained by economy-wide shifts in the composition of industries or demand for specific skills/ jobs associated with occupations and how much variation can be attributed to other individual specific circumstances. The individual characteristics considered include among others labour market experience, education, family situation, type of contract and wage quintile. Individual wages should therefore capture additional (unobserved) information about the person's skills/job quality, above the average effects associated with occupations, and other observable characteristics like education and labour market experience. Due to data availability, our analysis focuses on employees, which represented close to $83 \%$ of all workers at the start of the crisis.

Our results suggest that the probability of staying in employment, from one year to the next, is positively related to monthly earnings during both boom and early bust. The gradient with wages, however, is much more marked in the bust and remains significantly so even after controlling for a range of characteristics including industries or occupations. Overall, the results are consistent with the argument that, at least in the early part of the crisis, employers tried to retain skilled (well-paid, well-educated and experienced) workers, while taking advantage of the flexibility of part-time workers. One interpretation is that earnings also reflect unobservable differences in skills, experience or firm-specific human capital that are valued by employers, resulting in the positive association that is estimated here.

The paper is organised as follows: Section 2 discusses the data used in the analysis. Section 3 presents some descriptive statistics for the Great Recession in Ireland based on this data. Section 4 reports the findings of our empirical analysis, and Section 5 concludes.

\section{Data and sample selection}

Our analysis is based on data from the EU Survey on Income and Living Conditions (EU-SILC) for Ireland. The survey, conducted by the Central Statistics Office (CSO), was initially available for a small sample of households in 2003. It has been carried out annually on the full sample since 2004. The main advantage of using this data source-compared to labour force survey data-is that it not only provides details on individuals' labour market history but also includes information on their wages and on a wide range of individual and household characteristics-like education, children and health status-that may affect labour market circumstances. 
To investigate the impact of the crisis on the distribution of job loss, we need to be able to identify the individuals who moved out of employment (in the months) prior to the interview. To do so, we consider the information provided by the 13-month labour market recall questions available in each year of the survey. This information provides a useful time dimension to explore shifts in employment participation, over a year, for the entire sample (cross-sectional dimension of the survey). Only a quarter of interviewees are re-contacted 12 months later for the follow-up interview (longitudinal dimension of the survey).

Unfortunately, the reason why a person may have moved out of employment over the recall period is not documented. Presumably, during the boom, in the context of a buoyant economy, a large share of exits from employment will reflect quits. In contrast, at the start of the crisis, with a decline in demand and increase in economic uncertainty, a large share of exits from employment are likely to reflect dismissals. In fact, in the context of a slowdown, employees may opt to remain in their current employment position and therefore, the number of employee-initiated separations may decline.

To identify the effect of the crisis on the labour market, we look at who are the employees who moved out of employment (over a 12-month period) during boom years and compare this situation with what happened at the start of the crisis. Overall, results are quite similar across all boom years available (2004 to 2007), in spite of inevitable year-to-year variation in the sample. But, data for 2004 does not include information on industries, and evidence suggests that employment in some industries started slowing down in 2007 although the total number of jobs kept on increasing up to Q1 2008 (seasonally adjusted QNHS series). We therefore selected 2006 as the reference boom year in our analysis. This year is also the boom year with the lowest share of people staying in employment at the bottom of the wage distribution. Comparisons of labour market deterioration at the bottom of the wage distribution evaluated against this year are consequently useful because they represent lower bounds, relative to the other boom years in our sample. For comparison, results based on several combinations of boom year samples are reported in Table 7 in the Appendix.

Turning to the recession period, QNHS seasonally adjusted data indicate that the largest annual decline in total employment occurred during 2009. The peak (2008Q1) to trough (2012Q3) decline in employment was 15 percentage points, with the number employed falling by 7.5 percentage points between Q1 2009 and Q1 2010 (compared with 3.5 percentage points during 2008 and 3 percentage points during 2010).

Statistics computed on SILC data reveal a similar pattern with a slowdown in the labour market in 2008, a large deterioration in 2009 and slower but continued worsening in 2010. For example, the share of working-age people at work reached $65 \%$ in 2006 and 2007, declined slightly to $63 \%$ in 2008, dropped to $57 \%$ in 2009 and continued to decline to $55 \%$ in 2010; see Table 1 . The decline in the share of employees who changed jobs during the preceding year, and especially those who changed "to take up a better position", is a further sign of the labour market deterioration as the recession progressed. It is reasonable to suppose that, in times of uncertainty, employees are less willing to take risks and tend to stay in their existing employment position if they can. Another striking trend in this data is the growing share of employees working parttime. This probably reflected employees' preferences up to 2007. A very low share of part-time employees reported wanting more hours but not being able to do so between 
Table 1 Population aged 18-64, unless otherwise specified, various characteristics, 2004-2010

\begin{tabular}{llllllll}
\hline & 2004 & 2005 & 2006 & 2007 & 2008 & 2009 & 2010 \\
\hline At work & 63.5 & 64.3 & 64.8 & 64.7 & 62.8 & 57.0 & 55.3 \\
Works as an employee & 52.0 & 52.9 & 53.8 & 53.2 & 52.2 & 47.2 & 45.2 \\
Share of people aged 21-35 who have never worked & 9.4 & 9.0 & 8.4 & 8.6 & 8.5 & 10.8 & 10.4 \\
$\begin{array}{l}\text { All people working as employees } \\
\text { Works low hours (self-reported status) }\end{array}$ & & & & & & & \\
$\quad$ Wants but cannot find work for longer, \% hours", \% & 22.6 & 23.4 & 24.7 & 28.0 & 27.2 & 31.2 & 32.4 \\
Has changed job in the last 12 months, \% & 7.3 & 8.5 & 2.3 & 2.6 & 3.7 & 8.6 & 9.9 \\
$\quad \begin{array}{l}\text { To "take up or seek a better job" or "to retire or live } \\
\text { off private means"d, \% }\end{array}$ & 3.6 & 4.4 & 6.1 & 6.0 & 5.3 & 3.2 & 1.8 \\
Average of total usual weekly hours (all jobs) & 35.1 & 34.9 & 34.6 & 34.5 & 34.5 & 33.3 & 33.0 \\
\hline
\end{tabular}

Source: authors' computations from SILC data

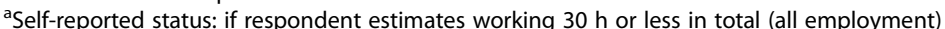

bIf respondent self-reported working less than $30 \mathrm{~h}$ a week and would like "to work more hours, but cannot find a

full-time job or work more hours in this job"

"Includes promotions and new contracts with the same employer

${ }^{d}$ This question is asked to people who say they have changed jobs in the last 12 months. Other reasons for a job change include end of temporary contract, redundancy, business closure, marriage, childbirth, study, illness, other family reasons and not specified

2004 and 2007. As the economy slowed down, however, the share of employees wanting to work longer hours but not being able to do so increased to $3.7 \%$ in 2008 and more than doubled in 2009, approaching $10 \%$ in 2010, see Table 1.

We therefore use data for 2006 as the reference period for the boom and data for 2009 to investigate how the situation changed as the crisis took hold. Our focus on 2009 is motivated by two key observations. First, 2009 saw the most substantial decline in the number of people employed. Second, 2009 pre-dates most of the rebalancing of the pool of people employed that occurred during the crisis. To consider robustness of our results, and given the timing of the interviews in 2009 (see Section 2.2), we also present results for the combined 2009 and 2010 recession years in Table 8 of the Appendix. These are not substantively different from the results based on data for 2009 only.

Note that although most of the decline in employment in Ireland happened along the extensive (headcounts) rather than intensive (hours) margin, job loss figures are likely to understate the full extent of the deterioration in the labour market, ${ }^{4}$ which included pay cuts especially in the public sector (see, e.g. Doris et al. 2015). In addition, we look at the characteristics of employees who are moving out of an employee position. Data from the QNHS suggest that the rate of job loss has been even higher among the selfemployed. Finally, with less jobs being created during the crisis, our current focus on flows out of employment is likely to understate the total shift in the labour market between boom and bust as highlighted, for example, by the increase in the number of young people who had never worked in 2009 and 2010 in Table 1.

\subsection{Sample selection}

The sample for analysis includes all respondents who stated that they were working as an employee (full-time or part-time) 12 months prior to the month of the interview 
and are aged 18-64 at the time of the interview. From this first selection are excluded respondents who, at the time of the interview, indicated that they had never worked. This selection excludes jobs classified as "vacations jobs undertaken by students, from which they return to studies or to other non-work situation, and any other casual work undertaken from time to time". Also omitted are a few respondents who stated working as an employee at the start of the period but who report no employment income for the 12 months prior to the month of the interview. This group consists mostly of people who are employed as family workers and people who report no employment income but some self-employment income over the period. The final sample includes 4231 people who were employed 12 months prior to the interview in 2006 and 3608 people who were employed 12 months prior to the interview in $2009 .^{5}$

\subsection{Dependent variable}

We are interested in the probability of being employed at the end of the year (at the interview), for people who were employed at the start of the year (start of the recall period). These employees are then defined as "employed" at the end of the period if they state working as an employee, in an apprenticeship or in a community employment scheme at the time of the interview, and either have worked for at least $1 \mathrm{~h}$ (for payment or profit) in the last week or are currently on (fully or partially) paid leave. ${ }^{6}$

In other words, we compare the probability of an employee being in employment at the interview in 2006 and in 2009, conditional on that person being employed at the start of the recall period, that is, 13 months earlier. For the people who were interviewed in 2006, this implies estimating the probability of them being in employment in 2006, provided they were also employed in 2005. These results are then compared the probability of being in employment in 2009, for the people employed in 2008. ${ }^{7}$ Overall, the end of period employment probability among employees in our sample declined substantially from 0.927 in 2006 to 0.875 in $2009 .^{8}$

\subsection{Labour market variables}

At the time of the interview, respondents were asked to provide information on a range of labour market characteristics. For the purpose of our analysis, we need information on individuals' labour market characteristics at the start of the recall period in order to assess the link between their labour market characteristics and probability of being employed at the end of the period. Usefully, many of the questions that were asked regarding respondents' labour market situation (e.g. industry, occupation, size of company, supervisory position, labour market experience or type of contract) were also asked with reference to the last position held, if the respondent was not working at the time of the interview.

For certain variables, like industry, occupation or the type of contract, the information collected at the time of the interview could be problematic, however, if the person changed jobs over the 12 months prior to the interview. Note that job changes include a change of contract with the same employer.

The reason provided for the job change was used to correct for the "start of period" type of contract. That is, if the reason for the job change was due to "the end of a temporary contract", the start of period contract was re-coded as temporary. Based on the 
information provided, it is not possible to know if an employee also changed industry or occupation when they changed jobs. It is hoped that, if this happened, the numbers will be small enough not to drive our results. Our main results do not seem to be sensitive to the exclusion of job changers; see Table 9 in the Appendix.

\section{Some descriptive statistics}

Individuals were asked to report their employee (cash or near cash) income for the period covering the 12 months prior to the month of the interview. ${ }^{9}$ From that information, we can compute individuals' average monthly employment income by dividing the total employment income (reported for the 12 months prior to the interview) by the number of months spent in employment over that period. ${ }^{10}$ This average monthly employment income is then used as a proxy for the start of period monthly wage.

To keep the analysis tractable, we collapse the earnings distribution into five quintiles. Quintiles are computed on the whole sample of employees present at the start of each period. The probability of being in employment at the end of the period, by start of period wage quintiles, is presented in the second column of Table 2. The top part of the table reports figures for 2006, and the bottom part reports statistics for 2009.

Two important trends emerge from this data. First, the probability of being employed at the end of the period is increasing with average monthly earnings, in both boom and bust. Employees in the top wage quintiles are at least 15 percentage points more likely to be in employment at the end of the period than employees in the lowest quintile. As mentioned earlier, data for 2006 shows the steepest wage gradient in boom years, with the lowest end of period employment rate in the bottom quintile (Q1) and the largest difference in employment rates between Q1 and Q5. Statistics computed on the 2004-2006 boom period are reported in Tables 5 and 6 in the Appendix. Second, the share of employees in employment at the end of the period declined at all quintiles in 2009, compared to 2006, with the largest relative drop for middle-wage earners. The probability of employment at the middle quintile declined by $8 \%$, from 0.948 to 0.873 between 2006 and 2009 .

Note that the current definition of earnings does not take into account the number of hours worked. Although we know whether a person worked part-time or full-time (self-reported status) in each of the months prior to the interview, we do not have information on the number of hours worked each month. Therefore, while part-time employees are present throughout a large part of the earnings distribution, they are over-represented towards the bottom. Our measure of wage therefore is a closer approximation of the total cost of the employee to the employer than individual skills-as measured by average hourly earnings-although it could be argued that part-time jobs also tend to be low-skill jobs.

To get a better understanding of factors that may underlie shifts in the relationship between earnings quintiles and end of period employment rates, Table 2 presents statistics for sub-groups of employees who tend to be concentrated at the top or bottom of the wage distribution or who are known to have been particularly hit by the crisis (e.g. construction workers). For each sub-group, two columns of figures are reported. The first column indicates the difference in end of period employment rates from the 
Table 2 Average end of period employment probabilities by quintile, for all employees and selected sub-groups, 2006 and 2009

\begin{tabular}{|c|c|c|c|c|c|c|c|c|c|c|c|c|c|c|}
\hline \multirow[t]{3}{*}{ Year } & \multirow{3}{*}{$\begin{array}{l}\text { Wage } \\
\text { quintile }\end{array}$} & \multirow{3}{*}{$\begin{array}{l}\text { Average } \\
\text { probability } \\
\text { of being } \\
\text { employed } \\
\text { at the end } \\
\text { of the } \\
\text { period } \\
\text { By quintile }\end{array}$} & \multirow{2}{*}{\multicolumn{2}{|c|}{$\begin{array}{l}\text { Employees with third-level } \\
\text { education }\end{array}$}} & \multirow{2}{*}{\multicolumn{2}{|c|}{$\begin{array}{l}\text { Employees who } \\
\text { started part-time }\end{array}$}} & \multirow{2}{*}{\multicolumn{2}{|c|}{$\begin{array}{l}\text { Selected industries } \\
\text { Construction + other } \\
\text { production }\end{array}$}} & \multicolumn{6}{|l|}{ Selected occupations } \\
\hline & & & & & & & & & \multicolumn{2}{|l|}{$\begin{array}{l}\text { Managers and senior } \\
\text { officials }\end{array}$} & \multicolumn{2}{|c|}{$\begin{array}{l}\text { Professionals + } \\
\text { associate prof } \\
\text { and technicians }\end{array}$} & \multicolumn{2}{|c|}{$\begin{array}{l}\text { Skilled trades + plant } \\
\text { and machine operatives }\end{array}$} \\
\hline & & & $\%$ dif from year avg & Share, row & $\begin{array}{l}\% \text { dif from } \\
\text { avg }\end{array}$ & Share, row & $\begin{array}{l}\% \text { dif from } \\
\text { year avg }\end{array}$ & Share, row & $\%$ dif from year avg & Share, row & $\begin{array}{l}\% \text { dif from } \\
\text { year avg }\end{array}$ & Share, row & $\begin{array}{l}\% \text { dif from } \\
\text { year avg }\end{array}$ & Share, row \\
\hline \multirow[t]{6}{*}{2006} & Q5 & 0.978 & 1.2 & 0.57 & & 0.02 & -1.2 & 0.20 & -0.7 & 0.24 & 0.3 & 0.50 & -0.3 & 0.12 \\
\hline & Q4 & 0.970 & -1.4 & 0.28 & -16.0 & 0.04 & 0.7 & 0.29 & -1.2 & 0.14 & -0.3 & 0.36 & 0.3 & 0.21 \\
\hline & Q3 & 0.948 & -1.1 & 0.20 & 2.4 & 0.10 & -0.9 & 0.33 & 0.8 & 0.12 & 0.2 & 0.21 & -0.6 & 0.22 \\
\hline & Q2 & 0.913 & 0.6 & 0.10 & 2.8 & 0.21 & -5.7 & 0.21 & 1.7 & 0.07 & -2.4 & 0.11 & -5.0 & 0.21 \\
\hline & Q1 & 0.828 & -9.2 & 0.06 & 1.1 & 0.76 & -3.9 & 0.11 & 4.1 & 0.04 & -11.4 & 0.07 & 10.6 & 0.10 \\
\hline & Avg & 0.927 & 2.8 & 0.24 & -6.2 & 0.23 & 0.0 & 0.23 & 3.0 & 0.12 & 2.7 & 0.25 & 0.9 & 0.17 \\
\hline \multirow[t]{6}{*}{2009} & Q5 & 0.951 & 1.3 & 0.56 & & 0.02 & -5.1 & 0.18 & 0.7 & 0.28 & 0.8 & 0.49 & -7.9 & 0.09 \\
\hline & Q4 & 0.923 & 4.6 & 0.35 & 5.1 & 0.08 & -13.0 & 0.23 & 4.1 & 0.14 & 2.6 & 0.36 & -8.2 & 0.16 \\
\hline & Q3 & 0.873 & 6.4 & 0.23 & 7.5 & 0.12 & -16.0 & 0.32 & 10.5 & 0.11 & 3.4 & 0.22 & -27.8 & 0.21 \\
\hline & Q2 & 0.859 & 6.4 & 0.16 & 7.6 & 0.27 & -17.2 & 0.20 & 10.6 & 0.06 & -6.2 & 0.14 & -9.3 & 0.14 \\
\hline & Q1 & 0.782 & 4.4 & 0.10 & 6.8 & 0.78 & -6.9 & 0.11 & 3.4 & 0.07 & -19.4 & 0.09 & -8.3 & 0.10 \\
\hline & Avg & 0.878 & 6.8 & 0.28 & 0.0 & 0.25 & -11.6 & 0.21 & 7.8 & 0.13 & 3.7 & 0.26 & -13.8 & 0.14 \\
\hline
\end{tabular}

Note: for each sub-group, the first column indicates the difference in end of period employment rates from the (quintile) average, in percent. The second column (italics) gives the \% of the quintile population in that sub-group. At least 30 observations per cell. Figures computed using sample weights 
(quintile) average of the same year, in percent. The second column (italics) reports the proportion of the quintile population in that sub-group. For example, looking at workers with third-level education in Q5 in 2006 reveals that $57 \%$ of employees in Q5 had third-level education (second column). Also, these employees' probability of being employed at the end of the period was about $1.2 \%$ higher than the average in Q5-i.e. they had a probability of about $99 \%\left(0.978^{*} 101.2\right)$ of remaining in employment in 2006.

Together, statistics for 2006 suggest that there was little difference in end of period average employment rates between the different sub-groups presented-this is also the case when looking at other characteristics of employees in 2006; see Tables 5 and 6 in the Appendix. By contrast, statistics for 2009 highlight large disparities in end of period employment probabilities between different sub-groups of employees.

There was a general increase in the proportion employees with third-level education between 2006 and 2009, from about 21 to $26 \%$ for men and from about 26 to $32 \%$ for women. While the share of people with third-level education has remained stable in the top quintile at around $56 \%$, it increased at all other quintiles. The share of employees with third-level education in the lowest quintile also rose over that period, from 6 to $10 \%$. On average, employees with third-level education are more likely than the population average, and by construction than employees with lower levels of education, to be employed at the end of the period, in 2006 and in 2009. In 2006, this advantage was closely related to their concentration in the top quintiles. The already higher average probability of being employed at the end of the period increased substantially for these groups, from $2.8 \%$ in 2006 to $6.8 \%$ in 2009, on average. In addition, the few highly educated employees in the bottom quintile tended to drop out more than the average for that quintile in 2006 (possibly reflecting a low attachment to their employment position). By 2009, employees with third-level education were more likely to be employed at the end of the period, in all quintiles, with the highest gains in the second and third quintiles.

Employees who started in a part-time position are found in all quintiles but, as expected, are over-represented in the bottom quintile where they account for more than $75 \%$ of employees in 2006 and in 2009. Part-time status is also linked to gender status with about $39 \%$ of female employees starting in a part-time position in 2006 and 2009, compared to around 9 to $14 \%$ of male employees in 2006 and 2009, respectively. While concentrated at the bottom of the distribution, the share of part-timers increased in all bottom four quintiles between 2006 and 2009. At the same time, a larger fraction of part-time workers report wanting to work longer hours and not being able to do so, see Table 1 . The increase in the average share of employees who started in a part-time position ${ }^{11}$ from $23 \%$ in 2006 to $25 \%$ in 2009 partly reflects the increase in men working part-time, increasing from $8 \%$ in 2006 to $14 \%$ in 2009. Figures for the top quintile are omitted given their small cell numbers (less than 30 observations).

In 2006, employees who started in a part-time position were on average $6.2 \%$ less likely to be in employment by the end of the period. This trend appears to reflect their concentration in the two lowest quintiles where continued employment rates are lower. Strikingly, the average employment disadvantage of part-timers disappeared in 2009, in spite of their ongoing concentration in the lowest quintiles. This shift reflects the large 
advantage experienced by employees who started on a part-time position in 2009, relative to full-timers in the same quintile. As full-timers are concentrated in higher quintiles where employment rates are also higher, the part-time advantage in lower quintiles cancels out on average in 2009. These figures nevertheless suggest that people on low hourly wages (i.e. people working full-time in lower quintiles) are particularly less likely to employed by the end of the period in 2009. As most part-time employees are also female employees, the part-time advantage in lower quintiles in 2009 could account for some of the relative advantage of women in lower quintiles in 2009.

As expected, outcomes varied significantly by industries in 2009. Employees working in construction and other production industries appear to have been particularly hit by the crisis. Their relative decline in employment rate is highest around the middle quintiles (between 13 and $17.2 \%$ ) where they are also concentrated. Overall, in 2009, these employees experienced an $11.6 \%$ lower probability of being in employment at the end of the period, compared to the average. This average was already much lower in 2009 than in 2006. In absolute terms, employees in construction and other production had a $77 \%$ chance of being employed at the end of the period in 2009 on average, down from a $92 \%$ probability in 2006. By contrast, employees in public administration, transport and communications industries appeared unaffected by the crisis, in 2009; see Tables 5 and 6 in the Appendix. These employees already had a slightly higher than average employment rate in 2006, at $95 \%$, which remained stable at the onset of the crisis, reaching $96 \%$ in 2009.

As reported in other studies, occupations are another dimension that delineates which employees had a high or low risk of moving out of employment during the crisis (e.g. Autor 2010; Mühlau 2014). In 2006, however, there was relatively little variation in end of period employment rates by occupation. At one end of the spectrum, "managers and senior officials" had a higher than average probability of staying employed (95.1\% compared to $92.7 \%$ for all employees). At the other end, employees in "elementary occupation" had a probability of $89.3 \%$ of being employed by the end of the period. The average variation between occupations in 2006 was therefore much smaller than the average variation by quintiles. In 2009, managers and other senior officials remained the occupational group with the highest end of period employment rate. Although at a slightly lower rate than in 2006, their end of period employment rate of $93.9 \%$ remained well above to the average of $87.7 \%$. Their relative advantage was greatest at the middle quintiles.

Professionals and associated professionals/technicians are another groups of employees who tend to be concentrated in top quintiles. They have maintained a slight advantage in 2009, relative to the average, in terms of end of period employment rates. Unlike managers, however, these employees move out of employment at a larger than the average rate in the two lower quintiles. This tendency, driven by associate professionals and technicians, appears to have worsened at the onset of the crisis. These figures suggest that highly skilled employees are more likely than the average to remain in employment, especially if they are in the highest earnings quintiles. Interestingly, the share of professionals and associated professionals has increased in the two lowest quintiles in 2009.

Skilled manual workers (skilled trades and machine/plant operatives ${ }^{12}$ ) have been by far the worst hit occupational group in 2009. These employees display a lower 
than average probability of being employed at the end of the period of at least $7.9 \%$, in all quintiles. Their largest relative penalty (27.8 \% lower than the average) relates to the middle quintile, where these workers are most represented. This trend translates in an average probability of $75.3 \%$ of being employed by the end of the period in 2009. By contrast, employees working in secretarial and administrative occupations (Tables 5 and 6 in the Appendix), and which are also clustered around the middle quintiles, had a much higher end of period average employment rate, reaching $89.8 \%$ in 2009 . This is even slightly higher than the population average of $87.5 \%$.

Employees in the remaining three occupational groups (personal service occupations, sales and customer service occupations and elementary occupations) tend to be concentrated in the lower wage quintiles. Together, in 2009, these three occupational groups accounted for $61 \%$ of all employees in the lowest quintiles and $50 \%$ of employees in the second lowest quintile. Their experience varied substantially across occupations, employees in personal and occupation services doing better than average and people in sales and elementary occupations being relatively more penalised; see Section 6.2 in the Appendix for more discussion and descriptive statistics on other individual characteristics.

\section{Probit analysis}

The descriptive statistics presented above suggest that the probability of exit from employment, as reported in SILC data, is inversely related to the start of period monthly earnings. These figures also indicate that end of period employment rates were lower in all quintiles in 2009 compared to earlier boom years. Additionally, the gradient with wages increased at the start of the crisis. In 2006, the probability of remaining in employment over the 12-month recall period was about $15 \%$ lower for employees in the bottom quintile than for employees in the top quintile (13\% lower in 2004-2006). By 2009, that gap had increased to about $18 \%$. There are, however, marked disparities in the employment outcome of different groups of employees across education levels, age, sectors or occupations. Additionally, employees with different characteristics tend to be clustered in different parts of the earnings distribution, which complicates the interpretation of the trends observed.

To get a better understanding of how the positive relationship between end of period employment rates and individual earnings is related to individual characteristics, we run a probit analysis on the probability of being in employment in the month of the interview. Our analysis is based on the full cross-sectional data from the 2006 and 2009 SILC samples, taking advantage of the 12-month recall period, as discussed in the previous section. Results based on other combinations of boom and bust years are reported in Tables 7 and 8 in the Appendix.

We control for employees' initial location in the earnings distribution and a range of other variables that may influence the probability that an individual may move out of employment; see bottom of Table 3 for the list of controls included. We compare findings for 2006 and 2009 to assess how the relationship has changed with the crisis. We want to know, in particular, whether the inclusion of additional controls dampens the relative employment advantage of people in top quintiles and whether these effects vary between boom and crisis years. 
Table 3 Average marginal effects from probit regressions, whole sample

\begin{tabular}{|c|c|c|c|c|c|c|c|c|}
\hline & 1 & 2 & 3 & 4 & 5 & 6 & 7 & 8 \\
\hline Year & 2006 & 2009 & 2006 & 2009 & 2006 & 2009 & 2006 & 2009 \\
\hline \multirow[t]{2}{*}{ Q2 } & $0.085^{* *}$ & $0.077^{*}$ & $0.079^{* * *}$ & $0.136^{* * *}$ & $0.084^{* * *}$ & $0.132^{* * *}$ & $0.082^{* * *}$ & $0.132^{* * *}$ \\
\hline & $(0.0182)$ & $(0.0307)$ & $(0.0201)$ & $(0.0294)$ & $(0.0198)$ & $(0.0302)$ & $(0.0198)$ & $(0.0304)$ \\
\hline \multirow[t]{2}{*}{ Q3 } & $0.120^{* *}$ & $0.090^{* *}$ & $0.113^{* * *}$ & $0.152^{* * *}$ & $0.119^{* * *}$ & $0.160^{* * *}$ & $0.117^{* * *}$ & $0.160^{* * *}$ \\
\hline & $(0.0148)$ & $(0.0303)$ & $(0.0184)$ & $(0.0320)$ & $(0.0183)$ & $(0.0306)$ & $(0.0184)$ & $(0.0311)$ \\
\hline \multirow[t]{2}{*}{ Q4 } & $0.142^{* *}$ & $0.140^{* *}$ & $0.142^{* * *}$ & $0.192^{* * *}$ & $0.148^{* * *}$ & $0.198^{* * *}$ & $0.142^{* * *}$ & $0.187^{* * *}$ \\
\hline & $(0.0120)$ & $(0.0227)$ & $(0.0142)$ & $(0.0276)$ & $(0.0140)$ & $(0.0281)$ & $(0.0146)$ & $(0.0279)$ \\
\hline \multirow[t]{2}{*}{ Q5 } & $0.150^{* *}$ & $0.169^{* *}$ & $0.134^{* * *}$ & $0.201^{* * *}$ & $0.141^{* * *}$ & $0.197^{* * *}$ & $0.133^{* * *}$ & $0.187^{* * *}$ \\
\hline & $(0.0105)$ & $(0.0191)$ & $(0.0161)$ & $(0.0263)$ & $(0.0161)$ & $(0.0275)$ & $(0.0161)$ & $(0.0275)$ \\
\hline Base controls & & & $x$ & $x$ & $x$ & $x$ & $x$ & $x$ \\
\hline Occupation dummies & & & & & $x$ & $x$ & & \\
\hline Industry dummies & & & & & & & $x$ & $x$ \\
\hline \multicolumn{9}{|l|}{ Tests on coefficients } \\
\hline $\mathrm{Q} 2=\mathrm{Q} 3$ & 0.028 & 0.652 & 0.031 & 0.487 & 0.024 & 0.181 & 0.023 & 0.211 \\
\hline $\mathrm{Q} 2=\mathrm{Q} 4$ & 0.001 & 0.008 & 0.001 & 0.003 & 0.001 & 0.001 & 0.001 & 0.005 \\
\hline $\mathrm{Q} 2=\mathrm{Q} 5$ & 0.001 & 0.001 & 0.001 & 0.001 & 0.001 & 0.002 & 0.001 & 0.010 \\
\hline Education dummies $=0$ & & & 0.577 & 0.001 & 0.572 & 0.004 & 0.582 & 0.007 \\
\hline Age dummies $=0$ & & & 0.004 & 0.129 & 0.004 & 0.051 & 0.020 & 0.114 \\
\hline Kids controls $=0$ & & & 0.001 & 0.010 & 0.001 & 0.015 & 0.001 & 0.005 \\
\hline Occupation dummies $=0$ & & & & & 0.657 & 0.001 & & \\
\hline Industry dummies $=0$ & & & & & & & 0.301 & 0.001 \\
\hline Pseudo $R^{2}$ & 0.078 & 0.043 & 0.189 & 0.116 & 0.193 & 0.151 & 0.195 & 0.153 \\
\hline Observations & 4231 & 3608 & 4175 & 3585 & 4167 & 3583 & 4170 & 3577 \\
\hline
\end{tabular}

Top of the table: std errors in parentheses; ${ }^{* * *} p<0.01,{ }^{* *} p<0.05,{ }^{*} p<0.1$. Base controls: female dummy; share of time worked part-time in the last 12 months; education and age dummies; permanent contract dummy; reported years of work experience; poor health status dummy; partner dummy for women and for men; and number of children aged 0-1, aged 1-5 and aged 6 and over. See text and Section 6.1 in the Appendix for more details on the construction of variables. Tests on coefficients: $p$ values reported; $p$ values in italics indicate that the test cannot be rejected at the $10 \%$ significance level; small $p$ values were rounded up to 0.001

Average marginal effects for earnings quintile dummies are reported in the top part of Table 3. We only report results for quintile dummies-Q1 as default category-for clarity. Results for the other variables are discussed in the text. The marginal effects were computed using the "margeff" program for STATA. The advantage of using margeff in the current analysis is that it allows for the estimation of marginal effects for sets of dummies that form a single underlying categorical variable, like the quintile dummies; see Bartus (2005) for more details. ${ }^{13}$ The middle part of Table 3 indicates which other explanatory variables have been included in the regression. The lower part of the table reports tests on different groups of variables. These tests also indicate whether certain variables are (jointly) significant in 2006 or in 2009. Table 4 reports related results for men and women separately, although the samples being much smaller than the coefficients are not as precisely estimated. Quintiles in the male and female subsamples are computed on the whole sample, so that average monthly earnings remain comparable across quintiles. 
Table 4 Average marginal effects from probit regressions, male and female sub-samples

\begin{tabular}{|c|c|c|c|c|c|c|c|c|c|c|c|c|}
\hline & \multicolumn{6}{|l|}{ Men } & \multicolumn{6}{|l|}{ Women } \\
\hline & $\overline{1}$ & 2 & 3 & 4 & 5 & 6 & $\overline{7}$ & 8 & 9 & 10 & 11 & 12 \\
\hline Year & 2006 & 2009 & 2006 & 2009 & 2006 & 2009 & 2006 & 2009 & 2006 & 2009 & 2006 & 2009 \\
\hline \multirow[t]{2}{*}{ Q2 } & $0.075^{* *}$ & 0.075 & $0.065^{* *}$ & $0.105^{* *}$ & $0.067^{* *}$ & $0.095^{*}$ & $0.094^{* * *}$ & $0.091^{* *}$ & $0.093^{* * *}$ & $0.139^{* * *}$ & $0.098^{* * *}$ & $0.143^{* * *}$ \\
\hline & $(0.0322)$ & $(0.0510)$ & $(0.0316)$ & $(0.0532)$ & $(0.0316)$ & $(0.0521)$ & $(0.0221)$ & $(0.0382)$ & $(0.0258)$ & $(0.0317)$ & $(0.0253)$ & $(0.0331)$ \\
\hline \multirow[t]{2}{*}{ Q3 } & $0.116^{* * *}$ & $0.090^{*}$ & $0.085^{* * *}$ & $0.128^{* *}$ & $0.084^{* * *}$ & $0.135^{* *}$ & $0.128^{* * *}$ & $0.124^{* * *}$ & $0.129^{* * *}$ & $0.158^{* * *}$ & $0.135^{* * *}$ & $0.158^{* * *}$ \\
\hline & $(0.0250)$ & $(0.0500)$ & $(0.0311)$ & $(0.0553)$ & $(0.0315)$ & $(0.0535)$ & $(0.0181)$ & $(0.0313)$ & $(0.0221)$ & $(0.0294)$ & $(0.0217)$ & $(0.0313)$ \\
\hline \multirow[t]{2}{*}{ Q4 } & $0.151^{* * *}$ & $0.141^{* * *}$ & $0.125^{* * *}$ & $0.172^{* * *}$ & $0.117^{* * *}$ & $0.163^{* * *}$ & $0.129^{* * *}$ & $0.165^{* * *}$ & $0.156^{* * *}$ & $0.207^{* * *}$ & $0.149^{* * *}$ & $0.198^{* * *}$ \\
\hline & $(0.0177)$ & $(0.0396)$ & $(0.0191)$ & $(0.0517)$ & $(0.0200)$ & $(0.0487)$ & $(0.0195)$ & $(0.0234)$ & $(0.0194)$ & $(0.0256)$ & $(0.0194)$ & $(0.0271)$ \\
\hline \multirow[t]{2}{*}{ Q5 } & $0.152^{* * *}$ & $0.206^{* * *}$ & $0.106^{* * *}$ & $0.175^{* * *}$ & $0.088^{* * *}$ & $0.163^{* * *}$ & $0.150^{* * *}$ & $0.147^{* * *}$ & $0.156^{* * *}$ & $0.184^{* * *}$ & $0.154^{* * *}$ & $0.170^{* * *}$ \\
\hline & $(0.0178)$ & $(0.0288)$ & $(0.0220)$ & $(0.0425)$ & $(0.0221)$ & $(0.0400)$ & $(0.0137)$ & $(0.0281)$ & $(0.0223)$ & $(0.0317)$ & $(0.0216)$ & $(0.0339)$ \\
\hline Base controls & & & $x$ & $x$ & $x$ & $x$ & & & $x$ & $x$ & $x$ & $x$ \\
\hline Occupations & & & $x$ & $x$ & & & & & $x$ & $x$ & & \\
\hline Industries & & & & & $x$ & $x$ & & & & & $x$ & $x$ \\
\hline \multicolumn{13}{|l|}{ Tests on coefficients } \\
\hline $\mathrm{Q} 2=\mathrm{Q} 3$ & 0.119 & 0.761 & 0.403 & 0.511 & 0.468 & 0.267 & 0.085 & 0.317 & 0.057 & 0.436 & 0.038 & 0.560 \\
\hline $\mathrm{Q} 2=\mathrm{Q} 4$ & 0.002 & 0.104 & 0.008 & 0.042 & 0.034 & 0.033 & 0.097 & 0.011 & 0.001 & 0.002 & 0.006 & 0.013 \\
\hline $\mathrm{Q} 2=\mathrm{Q} 5$ & 0.001 & 0.001 & 0.076 & 0.034 & 0.394 & 0.047 & 0.001 & 0.086 & 0.002 & 0.102 & 0.004 & 0.351 \\
\hline Education dummies $=0$ & & & 0.152 & 0.001 & 0.379 & 0.001 & & & 0.663 & 0.043 & 0.554 & 0.146 \\
\hline Age dummies $=0$ & & & 0.049 & 0.001 & 0.051 & 0.001 & & & 0.810 & 0.268 & 0.862 & 0.237 \\
\hline Kids dummies $=0$ & & & 0.049 & 0.287 & 0.041 & 0.201 & & & 0.001 & 0.001 & 0.001 & 0.001 \\
\hline Occupations $=0$ & & & 0.044 & 0.001 & & & & & 0.132 & 0.311 & & \\
\hline Industries $=0$ & & & & & 0.153 & 0.001 & & & & & 0.086 & 0.665 \\
\hline Pseudo $R^{2}$ & 0.081 & 0.051 & 0.234 & 0.185 & 0.227 & 0.201 & 0.071 & 0.059 & 0.187 & 0.183 & 0.200 & 0.168 \\
\hline Observations & 2144 & 1804 & 2112 & 1793 & 2116 & 1789 & 2087 & 1804 & 2055 & 1790 & 2054 & 1788 \\
\hline
\end{tabular}

Notes: quintiles computed on the whole sample. Earnings thresholds for each quintile are therefore comparable across male and female regressions and with regressions presented in Table 3 on the whole sample. Top of the table: std errors in parentheses; ${ }^{* * *} p<0.01,{ }^{* *} p<0.05,{ }^{*} p<0.1$. Base controls: female dummy; share of time worked part-time in the last 12 months; education and age dummies; permanent contract dummy; reported years of work experience; poor health status dummy; partner dummy for women and for men; and number of children aged 0-1, aged 1-5 and aged 6 and over. See text and Section 6.1 in the Appendix for more details on the construction of variables. Tests on coefficients: $p$ values reported; $p$ values in italics indicate that the test cannot be rejected at the $10 \%$ significance level; small $p$ values were rounded up to 0.001 
Similar to the descriptive statistics reported above, results in columns 1-2 of Table 3 indicate that employees with monthly income in higher quintiles were significantly more likely to be employed by the end of the period than employees with wages in the bottom quintile, in boom and bust. In 2006, an employee with monthly earnings in the second quintile (Q2) had an 8.5 percentage point higher probability of being employed by the end of the period, than employees with a wage in the bottom quintile (Q1). For employees with earnings in the top quintile (Q5), the advantage was 15 percentage points. ${ }^{14}$

Looking first at results before the inclusion of other controls (columns 1-2, Table 3), the estimated marginal effect for Q5 is higher in 2009 than in 2006. This relative increase concerns the top two quintiles when comparing data for 2009 with data for a larger sample of boom years. For the middle and bottom quintiles in 2009, the coefficient for Q2 is not significantly different from zero (i.e. from Q1) at the $5 \%$ level, and the estimated coefficient for Q3 is not significantly different from Q2 (see tests for Q2=Q3). This suggests that, at the onset of the crisis, the relative position of workers in the middle and lower part of the wage distribution had significantly worsened relative to the situation of workers in Q4 and Q5.

These trends appear to be driven by what happens in the male sub-sample. Results in columns 7 and 8 of Table 4 suggest that the relative advantage of female employees in all quintiles, before the inclusion of other controls, did not change much between 2006 and 2009, except possibly for workers in Q4. For men, however, the relative advantage of employees in the top quintile increased substantially in 2009, while it declined for those in the second and middle quintiles (Q2 and Q3).

The inclusion of demographic and labour market controls (columns 3-4, Table 3) has little effect on the estimated marginal effects of all quintiles in 2006-except for a dampening of the estimated Q5 mainly driven by what happens to men. At the onset of the crisis, however, including base controls affects the estimated probability of staying in employment across the wage distribution in two ways. First, the relative advantage of employees in Q4 or Q5-compared to workers with a wage in the bottom quintile-becomes even larger. This trend is observed for both men and women and is slightly more marked in the larger 2009-2010 sample. Second, while the relative position of employees in Q3 improves relative to workers in Q1, it does not significantly improve relative to workers in Q2 and remains much lower than the probability estimated for Q4 and Q5. As a result, even with the inclusion of demographic and labour market controls, employees in Q3 remain relatively worse off than during the boom, when comparing their employment outcomes with employees in adjacent quintiles (Q2 and Q4). This effect is not as marked in the combined 2009-2010 sample. Adding industry or occupation controls does not alter these broad trends (columns 5-8).

To get a better idea of how these results fit in the wider picture and assess their magnitude, we discuss briefly some of the results for the other explanatory variables, starting with demographics. To allow for different exits of employment probabilities by gender, a female dummy is included. Women appear to have a significantly higher probability of remaining in employment in 2009, but this effect disappears with the inclusion of further controls. ${ }^{15}$

We consider three categories of the highest level of education completed: up to lower secondary (up to junior cert), higher secondary (leaving, advanced and higher 
cert) and all third-level degrees (incl. diploma). Education does not seem to have a significant impact on the probability of staying in employment in 2006 (and in other boom years), but third-level education is positively and significantly related to the probability of remaining employed in 2009. Similarly, education controls are jointly significant in 2009 but not in 2006. The magnitude of the effect varies between 5 and 7 percentage points, depending on the specification considered. Here again, education appears to be particularly important in the male sub-sample in 2009. The increased importance of education for employment during the crisis is also reported in the study by Kelly and McGuinness (2015), based on QNHS data for 2006 and 2011.

Non-parametric age effects are also included. The employees are grouped into eight categories: aged 18-23, 24-29, 30-35, 36-41, 42-47, 48-53, 54-59 and 60-64. We also considered different age categorisations; see Section 6.3 in the Appendix. All approaches suggested evidence of early retirement for older workers during the boom, although the effect was smaller when considering larger age bands. Age dummies are usually jointly significant in boom years (effect driven by the male sub-sample).

The partner variable is constructed on the actual observed number of people living in the same household and their reported relationships to one another. This variable was interacted with gender to allow for separate male and female effects associated with having a partner. Similarly, children are allocated to the parent(s) who live(s) in the same household at the time of the interview. This definition implies that stepparents living in the same household are considered as parents in our analysis, whereas parents who are not living with their child will be coded as having no children. For each parent, the number of children living in the household is grouped into babies (children aged 0-1), children aged 1-5 and children aged 6 and above. The number of babies in the household is significantly inversely related to employment outcomes, with an average effect varying between 4 and 7 percentage points in boom years and around 5 percentage points in 2009. The presence of children in the household is an important determinant of the employment outcome of female employees. Several other combinations of child and partner/marital status variables have been considered, with no impact on the results. See Section 6.3 in the Appendix for more discussion.

Poor health status at the time of the interview (end of the period) may have had a direct effect on the respondent's probability of moving out of employment. A health dummy was coded one if the person reported bad or very bad health, as opposed to fair, good or very good health. Respondents who reported poor health at the interview were significantly less likely to be in employment at the end of the period, in 2006 and in 2009. The effect is on the larger side in 2009, of about 10 percentage points, compared to about 4.5 to 8 percentage points in boom years depending on the specification considered.

Turning now to labour market controls, we do not have information on the number of hours an employee has worked each week or month, but we know whether the person has worked part-time or full-time in each of the months the person worked prior to the interview. The share of time worked part-time is included as a control in the regressions. This variable is defined as the number of months spent in part-time work out of the total number of months spent in employment over the 12 months prior to the interview. ${ }^{16}$ 
The descriptive analysis pointed to the shift in the average exit probability of parttime employees, from an above average exit rate in 2006 to a below average exit rate in 2009. But, part-time employees also tend to be over-represented in lower quintiles where the average exit rate is higher. Controlling for wages, part-time status is associated with a significantly higher probability of being employed at the end of the period, reaching 9 to 10 percentage points, in 2009, while the effect implies an advantage of 3 percentage points or less in 2004 to 2006. This apparent growing importance of parttime work at the onset of the crisis relates to trends observed in other European countries, with a significant share of job creation in Europe in recent years being in parttime and casual work. The estimated marginal effects of all wage quintiles increase when the part-time control is included in the regression in 2009. This dummy, which is strongly positive in 2009, remains significant with the inclusion of a wide range of other controls, while its effect is much smaller or insignificant in boom years. This suggests that among those on low monthly wages, employees on low hourly wages have been particularly affected at the start of the crisis.

The type of contract (permanent vs. temporary) has an important bearing on the probability of staying in employment from one year to the next, during boom and crisis years. This may not be so surprising, but the magnitude of this effect is quite stable, between 16 and 11 percentage points in boom years, and around 11-13 percentage points in 2009, depending on the specification considered.

Occupation dummies were included as a separate step (columns 5-6 of Table 3). These were coded based on the employees' current or last reported job and organised in nine groups: senior officials and managers; professionals; technicians and associate professionals; administrative and secretarial positions; skilled trade occupations; personal and service occupations; sales and customer service occupations; plant and machine operatives; and elementary occupations. Occupations appear to be important as a predictor of employment outcomes in 2009, but the dummies are never jointly significant in 2006 or in other boom year combinations.

To take into account the effect of working in hard-hit industries, industry dummies are included in the last two columns of Table 3. Employees' industries are based on the NACE classification: agriculture; construction; other production; commerce and finance; transport and communication; professional services; public administration; and others. As with occupations, industry controls appear to be important as a predictor of employment outcomes in bust years but not in boom years. The industry effect in 2009 presented in Table 3 is driven by the employment outcomes of men (see Table 4). This follows the trend already observed in many other instances, that men tend to work in industries that are more sensitive to the business cycle, like production and construction. ${ }^{17}$

Other variables where considered but not included in the final analysis. We tried to control for company sizes, that is, if the respondent worked in a large company (50 or more employees) or in a very small company (10 employees or less). This follows the observation, for example, that small firms were more likely to go bankrupt during the Great Depression in the USA, see e.g. Margo (1992). Firm size dummies were not significant (even in the larger boom year samples) and had no impact on the results. Also, whether the respondent (last) worked in a supervisory position or whether the respondent had "a say in the pay or promotion of the people" supervised did not appear 
to be significantly related to the probability of being employed at the end of the period. This could also be attributable to the small number of employees concerned. Several combinations of regional controls as well as employees' partner's labour market status and education were also considered. Results using an extended set of explanatory variables are reported in Table 11 in the Appendix.

Other potentially relevant variables, however, could not be included in the analysis. Immigration status-defined either as people born abroad or as non-Irish citizens-could have a significant effect on the probability exit from employment, e.g. McGinnity et al. (2014) and Kelly and McGuinness (2015). This variable could not be included in the regressions as there were very few observations in 2009. The number of people identified as born abroad by the SILC data dropped from 1288 in 2007 to 601 in 2008, and to 79 in 2009. This sharp decline in the number of immigrants in the SILC samples does not reflect trends in the Irish population at the time. Whether a person worked in the public or private sector was only asked from 2007 onwards. Union memberships and tenure are other potentially important variables in this context that could only be inferred for people who were employed at the time of the interview.

\section{Conclusions}

The examination of the pattern of job loss with EU-SILC data in Ireland shows that employees on high wages (in Q4 and Q5) are more likely to stay employed than employees on lower earnings. Their relative advantage increased significantly with the onset of the Great Recession, and the scale of the crisis was felt more deeply across the lower and middle parts of the wage distribution.

In 2009, the inclusion of a large set of individual controls including industries and occupations further widens the gap in employment probability between employees in the top (Q5) and the bottom $(\mathrm{Q} 1)$ quintiles, while reduces slightly the relative gap between workers in the top (Q5) and lower middle of the earnings distribution (Q2 and Q3). Nevertheless, even after controlling for a large set of job and other individual characteristics, employees in the middle quintile remain relatively worse off during the crisis. That is, they experience statistically similar levels of job loss than workers in Q2, with employment rates lagging behind those of workers in Q4 and Q5. Our results suggest that they had a statistically significant and higher probability of remaining in employment than workers in Q2 during boom years. This trend appears to be driven by what happened in the male sub-sample in 2009 .

The fact that certain sectors were particularly hard hit, with construction experiencing a remarkable collapse, was key: skilled manual workers who might in other circumstances have been relatively protected were seriously affected, and the gendered nature of the job loss also reflects that sectoral pattern, with men making up a particularly large proportion of employees in the worst-affected sectors. Together, individual characteristics other than industries and occupations were predictors of movements out of employment in the preceding boom years. In contrast, occupation and industry dummies appear to be more informative as explanatory variables in the bust, lending support to a macroeconomic-type argument to the distribution of job loss during the crisis.

Occupations have been at the centre of recent research on job loss; our results show that occupation, together with industrial sector, was indeed an important 
predictor of job retention vs. loss during the Great Recession in Ireland but does not tell the whole story. There is still a significant effect attached to individual wages, even after controlling for occupations and a large set of other explanatory variables. Additionally, the positive relationship between wage quintile and the probability of staying in employment from one year to the next was steeper in the bust than in the boom. This could be an indication that there is an important omitted explanatory variable or that the wage effect reflects unobservable workers characteristics, including firm-specific human capital, that were particularly valued by the employer at the start of the crisis. ${ }^{18}$ Assuming that wages capture the effect of unobservable employees' skills, on top of observable differences-as proxied by occupation, labour market experience and education-our results imply that in the crisis, employers sought to retain highly paid and skilled workers and at the same time favoured part-time workers among employees in low wage quintiles. This highlights the role of firm-specific or employer decisions on the pattern of job loss during the crisis in Ireland.

The implications of these findings for how policymakers understand and respond to job loss in recession are worth bringing out. The fact that earners in the top two quintiles were sheltered from job loss even in such a severe recession, indeed that their relative advantage increased, helps shift the focus away from the professionals-notably architects and engineers-who featured prominently in media commentary on the impact of the crisis. However, the finding that those in the middle parts of the wage distribution experienced levels of job loss similar to workers lower down the distribution means that active labour market policy faces new challenges in dealing with a much broader and more diverse set of unemployed, in terms of skills, age and family circumstances and expectations, that need to be recognised into the design of programmes. The very distinctive sectoral pattern of job loss, in particular the extent of job destruction in construction, also has very significant implications for both the design and delivery of labour market programmes and for industrial policy more broadly, and indeed for the state's perspective on the benefits from infrastructural investment, notwithstanding fiscal constraints. Of course, bringing out these patterns of job loss also helps to reinforce the lessons from the boom years about policy mistakes and failures-notably in the regulation of property-related lending and the procyclical nature of public expenditure-that helped fuel the property boom and exacerbated the financial crisis, with construction sector workers in particular but a broad swathe of the workforce more broadly paying the price.

\section{Endnotes}

${ }^{1}$ From peak to trough, the rate of job loss in Ireland reached $9 \%$ for women compared to about $19 \%$ for men (figures relate period from 2008Q1 to 2012Q3, QNHS seasonally adjusted series).

${ }^{2}$ Job loss was initially sharper for men, with the trough in the third quarter of 2009 at almost $16 \%$, but the number of jobs started rising thereafter. In this sector, employment declined more slowly for women but reached a rate of job loss rate close to $19 \%$ at the trough, in the first quarter of 2014. 
${ }^{3}$ Other aspect of the employment relation that varies between occupations includes the length of contract, length of notice period, fringe benefits like sick leave, pension contributions, length of pay period, fixed pay vs. hourly pay, pay by shift, predictability of working hours, etc. Remuneration conditions are also likely to be affected by labour market regulations and union negotiations.

${ }^{4}$ Hours worked remained relatively stable within industries or occupations. See, e.g. O’Farrell (2013) and Mühlau (2014).

${ }^{5}$ Allowing for a broader definition of "previously employed" that includes people who stated working as an employee 12 and/or 11 months prior to the month of the interview had no impact on the results. Results based on the extended set of employees are reported in Table 10 in the Appendix.

${ }^{6}$ Employees on unpaid leave are therefore not considered to be employed at the time of the interview. This includes people with missing information on whether or not they receive payment during their leave.

${ }^{7}$ As SILC 2009 interviews were conducted between Dec. 2008 and Jan. 2010, we are technically comparing employees' working status at the start of the period (just before or at the very start of the crisis), between Nov. 2007 and Dec. 2008, with their employment situation at the end of the period (at the end of the year with the largest deterioration on the labour market), between Dec. 2008 and Jan. 2010.

${ }^{8}$ Compared to 0.928 in 2007, 0.908 in 2008 and 0.904 in 2010

${ }^{9}$ This timing is not necessarily the same in all the countries that conduct EU-SILC surveys, but it is in Ireland.

${ }^{10}$ Our analysis is based on gross income figures. Using net income provides a similar story.

${ }^{11}$ Whether an employee worked full-time or part-time is documented for each of the 12 months prior to the interview.

${ }^{12}$ Occupations in skilled trades include bricklayers; roofers; wall tillers; plumbers; precision instrument makers; computer engineers (installation and maintenance); scaffolders; motor mechanics, auto electricians, and tyre and exhaust fitters; carpenters; book binders; bakers; butchers; gardeners; and bus drivers. Occupations in plant or machine operatives include mechanical plant drivers/operatives and crane drivers; moulders and furnace operatives (metal); electroplaters, galvanisers and colour coaters; other automatic machine workers; assemblers and lineworkers (electrical and electronic goods); and electrical, energy, boiler and related plant operatives and attendants.

${ }^{13}$ The marginal effects estimated at the sample means of the independent variables (not reported) are smaller in magnitude but tell the same overall story.

${ }^{14}$ These percentage point differences correspond to the differences in average employment rates between quintiles in the sample, see Table 2. For example, the probability of being employed by the end of the period in 2006 was $97.8 \%$ for employees in Q5 and $82.8 \%$ for employees in Q1. The difference between the two figures gives 15 percentage points.

${ }^{15} \mathrm{~A}$ related study by Wilkins and Wooden (2011) on Australian data reports that women are less likely than men to be dismissed but that this effect disappears once controls, like industry and occupation, are also considered.

${ }^{16}$ In 2006 and 2009, only about $2 \%$ of respondents switched between full-time and part-time employment in the 12 months prior to the interview, and therefore, 
about $98 \%$ of respondents remained either in full-time or part-time work, throughout the period.

${ }^{17}$ There is a significant overlap between the occupation and industry classifications, and therefore, the impact of the two variables was considered separately. Including both sets of variables at the same time has little effect on the results.

${ }^{18}$ Or job characteristics that are valued by the employee-lower quit rate in higher quintiles

${ }^{19}$ These include police officers; chefs; cooks; waiters; nurses' aides and ambulance staff; childminders, nursery nurses and playgroup leaders; housekeepers (domestic and non-domestic); caretaker; and launderers, dry cleaners and pressers.

\section{Appendix}

\subsection{Labour market variables}

Overall, there are relatively few missing observations for each of the labour market variables considered, with a maximum of $3.6 \%$ of the unweighted sample of employees aged 18-65 for labour market experience, in 2006. Most of the missing observations on work experience are for young people aged 18-21 and who are also employed at the end of the period. Some of these missing observations could be imputed using additional information from variables like their age, the age at which the person started their first job and the number of years spent in unemployment or out of work. The number of years of (non-student type) work experience at the start of the period is then included in the base set of controls in the empirical analysis. It was computed using the information collected at the time of the interview, deducting 1 year for people who are still employed at the end of the period.

\subsection{Additional descriptive statistics and data discussion}

Additional descriptive statistics are reported in Tables 5 and 6 in the Appendix. These figures suggest that gender differences in end of period employment rates remained relatively small between periods, in the SILC sample. In 2006, male employees had a $1.5 \%$ higher probability than the average (i.e. than women) of being in employment at the end of the period. This advantage mainly reflects their concentration top quintiles where the end of period employment probabilities are also higher. In 2009, male employees had about a $4 \%$ lower probability than the average to remain in employment in all quintiles except the top quintile. But, they do not appear to be as penalised on average, reflecting their ongoing over-representation in top quintiles.

Older workers (aged 55-64) were 3 to $4.4 \%$ more likely than the average to be out of employment at the end of the period (in all quintiles except for the bottom one) in 2006. This could reflect a tendency for early retirement in 2006. There was more variation by quintiles for young workers (aged 18-30) in 2006, but the average difference with the sample was quite small at $-1.6 \%$. The situation of young workers worsened in 2009, while it improved for older workers, on average. It is also interesting to note the increase in the share of older workers and coincident decline in the proportion of young employees between 2006 and 2009. 
Looking at labour market characteristics, the share of employees on a permanent contract increased slightly in the lowest quintile, from $73 \%$ in 2006 to $75 \%$ in 2009, and declined slightly in the top quintile, from 98 to $95 \%$, leaving the average unchanged between 2006 and 2009, at about $89 \%$. In the two lowest quintiles, having a permanent contract is also associated with a higher than average probability of being employed at the end of the period, both in 2006 and 2009.

Employees in personal service occupations, sales and customer service occupations and elementary occupations tend to be found in the lower earning quintiles. Together, in 2009, these three occupational groups accounted for $61 \%$ of all employees in the lowest quintiles and $50 \%$ of employees in the second lowest quintile. The average situation of employees in personal and occupation services ${ }^{19}$ barely changed between 2006 and 2009, with a probability of $91.5 \%$ of being employed by the end of the period in 2006 and of $91 \%$ in 2009. For employees in sales and elementary occupations, their low performance in 2006 mainly reflected their concentration in the two lowest quintiles, where average employment rates are also lower. In 2009, sales and elementary occupation employees in the middle quintile had a $7 \%$ higher probability than the average to be employed by the end of the period. The relative situation of employees in these occupations at the very top, however, worsened significantly, although this concerns fewer employees. This trend suggests a reverse pattern than that found for professional and associated professionals, who are clustered at the top of the distribution. Employees in these occupations were relatively more penalised in top quintiles at the onset of the crisis.

\subsection{Additional controls and sensitivity analysis}

At the time of the interview, the highest level of education is recorded, and as our analysis excludes students, whose education level may have changed over the 12 months prior to the interview, the end of period education level will be the same as at the start of the period. We consider three categories of the highest level of education completed: up to lower secondary (up to junior cert), higher secondary (leaving and higher cert) and all third-level degrees (incl. diploma). Allowing for a finer grouping of five categories provided similar if less contrasted conclusions.

When controlling for age, we also considered finer age bands (using 16 age bands) or a combination of age groups into three age bands. All approaches suggested evidence of early retirement for older workers during the boom, although the effect was smaller when considering larger age bands. This is probably due to the fact that the effect is likely to be more diluted in a larger group. The age dummies were never/always jointly significant when considering 3/16 age groups, suggesting that age effects are better captured with narrower bands. No particular other effects on other variables can be noted, following a change in the age specification.

Regarding the partner variable, we only observe a person's cohabitation status at the date of the interview. In SILC data, the number of people living with a partner was stable to 2008 and increased in 2009 both in the wider population and in the employee sub-population. The observation that the rate of cohabitation increases 
in economic downturns is consistent both with the economies of scale that cohabitation confers (by reducing associated budgetary pressures) and an insurance motive in relation to increased labour market uncertainties. It is possible, however, that a person's employment status affects the probability of moving in or staying with a partner, rather than the reverse. We also tried to control for marital status and marital status conditional on the person living with the husband/wife, by gender, with no impact on the results.

Several other combinations of child variables have been considered, with no impact on the results. We tried to distinguish between households where babies (child up to 1 year old) were the only children below the age of 6 and households where babies had siblings below the age of 6 . We also tried to distinguish between the children aged 12-17 and those aged 18 or more. The number of children in each category was also replaced by a dummy indicating the presence or not of children in this age category, which provided weaker results. The inclusion/exclusion of any of these variables had little or no impact on the children controls currently included in the regression.

Table 5 Average end of period employment probabilities by quintile, for all employees and selected sub-groups, boom years and 2009

\begin{tabular}{|c|c|c|c|c|c|c|c|c|c|c|c|c|c|}
\hline \multirow[t]{4}{*}{ Year } & \multirow{4}{*}{$\begin{array}{l}\text { Wage } \\
\text { quintile }\end{array}$} & \multirow{3}{*}{\multicolumn{3}{|c|}{$\begin{array}{l}\text { All employees } \\
\text { Probability of } \\
\text { being employed } \\
\text { at the end of } \\
\text { the period }\end{array}$}} & & \multicolumn{8}{|c|}{ Employees with selected demographics } \\
\hline & & & & & & & & & & & & & \\
\hline & & & & & & \multicolumn{2}{|l|}{$\overline{M e n}$} & \multicolumn{2}{|c|}{$\begin{array}{l}\text { With second- } \\
\text { level education }\end{array}$} & \multicolumn{2}{|c|}{ Aged 55-64 } & \multicolumn{2}{|c|}{ Aged 18-30 } \\
\hline & & $\begin{array}{l}\text { Average } \\
\text { 2004-2006 }\end{array}$ & 2006 & & & $\begin{array}{l}\text { \% dif } \\
\text { from } \\
\text { avg }\end{array}$ & $\begin{array}{l}\text { Share, } \\
\text { row }\end{array}$ & $\begin{array}{l}\% \text { dif } \\
\text { from } \\
\text { avg }\end{array}$ & $\begin{array}{l}\text { Share, } \\
\text { row }\end{array}$ & $\begin{array}{l}\text { \% dif } \\
\text { from } \\
\text { avg }\end{array}$ & $\begin{array}{l}\text { Share, } \\
\text { row }\end{array}$ & $\begin{array}{l}\% \text { dif } \\
\text { from } \\
\text { avg }\end{array}$ & $\begin{array}{l}\text { Share, } \\
\text { row }\end{array}$ \\
\hline \multirow{8}{*}{$\begin{array}{l}\text { Boom } \\
\text { years }\end{array}$} & Q5 & 0.972 & 0.978 & & 2006 & 0.0 & 0.68 & 0.1 & 0.32 & -3.1 & 0.16 & -1.3 & 0.05 \\
\hline & Q4 & 0.963 & 0.970 & & & 0.6 & 0.65 & 1.6 & 0.48 & -4.0 & 0.12 & 0.5 & 0.22 \\
\hline & Q3 & 0.947 & 0.948 & & & -0.8 & 0.54 & 0.1 & 0.52 & -4.4 & 0.10 & -1.6 & 0.37 \\
\hline & Q2 & 0.912 & 0.913 & & & -1.4 & 0.44 & 1.7 & 0.61 & -3.0 & 0.09 & 2.7 & 0.44 \\
\hline & Q1 & 0.842 & 0.828 & & & -0.3 & 0.29 & 0.4 & 0.54 & 0.4 & 0.13 & -2.5 & 0.36 \\
\hline & Avg & 0.928 & 0.927 & & & 1.5 & 0.52 & 0.3 & 0.49 & -2.4 & 0.12 & -1.6 & 0.29 \\
\hline & & 2009 & $\%$ diff & th & & & & & & & & & \\
\hline & & & $\begin{array}{l}2004- \\
2006\end{array}$ & 2006 & & & & & & & & & \\
\hline \multirow[t]{6}{*}{ Bust } & Q5 & 0.951 & -2.1 & -2.8 & 2009 & 0.3 & 0.70 & 0.1 & 0.35 & -8.6 & 0.17 & & 0.04 \\
\hline & Q4 & 0.923 & -4.2 & -4.9 & & -3.7 & 0.54 & 0.4 & 0.43 & 0.9 & 0.14 & 1.5 & 0.21 \\
\hline & Q3 & 0.873 & -7.9 & -8.0 & & -4.0 & 0.59 & -4.4 & 0.49 & 3.9 & 0.12 & -3.5 & 0.31 \\
\hline & Q2 & 0.859 & -6.1 & -5.9 & & -4.2 & 0.45 & 0.3 & 0.57 & -5.0 & 0.13 & -1.5 & 0.39 \\
\hline & Q1 & 0.782 & -7.1 & -5.5 & & -4.4 & 0.32 & 1.3 & 0.51 & 6.1 & 0.16 & -1.7 & 0.32 \\
\hline & Avg & 0.878 & -5.4 & -5.4 & & -1.0 & 0.52 & -1.2 & 0.47 & -0.6 & 0.15 & -3.3 & 0.25 \\
\hline
\end{tabular}

Note: for each sub-group, the first column indicates the difference in end of period employment rates from the (quintile) average, in percent. The second column (italics) gives the $\%$ of the quintile population in that sub-group. At least 30 observations per cell. Figures computed using sample weights 
Table 6 Average end of period employment probabilities by quintile, for all employees and selected sub-groups, 2006 and 2009

\begin{tabular}{|c|c|c|c|c|c|c|c|c|c|c|c|c|}
\hline \multirow[t]{3}{*}{ Year } & \multirow[t]{3}{*}{$\begin{array}{l}\text { Wage } \\
\text { quintile }\end{array}$} & \multirow{3}{*}{$\begin{array}{l}\text { All } \\
\text { employees } \\
\text { Probability } \\
\text { of being } \\
\text { employed } \\
\text { at the end } \\
\text { of the } \\
\text { period } \\
\text { Average }\end{array}$} & \multirow{2}{*}{\multicolumn{2}{|c|}{$\begin{array}{l}\text { Labour } \\
\text { market } \\
\text { Started on a } \\
\text { permanent } \\
\text { contract }\end{array}$}} & \multirow{2}{*}{\multicolumn{2}{|c|}{$\begin{array}{l}\text { Selected industries } \\
\text { Public admin + } \\
\text { transport and } \\
\text { communication }\end{array}$}} & \multicolumn{6}{|c|}{ Selected occupations } \\
\hline & & & & & & & \multicolumn{2}{|c|}{$\begin{array}{l}\text { Personal } \\
\text { service } \\
\text { occupations }\end{array}$} & \multicolumn{2}{|c|}{$\begin{array}{l}\text { Administrative } \\
\text { and secretarial } \\
\text { occupations }\end{array}$} & \multicolumn{2}{|c|}{$\begin{array}{l}\text { Sales }+ \\
\text { elementary } \\
\text { occupations }\end{array}$} \\
\hline & & & $\begin{array}{l}\% \text { dif } \\
\text { from } \\
\text { year } \\
\text { avg }\end{array}$ & $\begin{array}{l}\text { Share, } \\
\text { row }\end{array}$ & $\begin{array}{l}\text { \% dif } \\
\text { from year } \\
\text { avg }\end{array}$ & $\begin{array}{l}\text { Share, } \\
\text { row }\end{array}$ & $\begin{array}{l}\% \text { dif } \\
\text { from } \\
\text { year } \\
\text { avg }\end{array}$ & $\begin{array}{l}\text { Share, } \\
\text { row }\end{array}$ & $\begin{array}{l}\% \text { dif } \\
\text { from } \\
\text { year } \\
\text { avg }\end{array}$ & $\begin{array}{l}\text { Share, } \\
\text { row }\end{array}$ & $\begin{array}{l}\% \text { dif } \\
\text { from } \\
\text { year } \\
\text { avg }\end{array}$ & $\begin{array}{l}\text { Share, } \\
\text { row }\end{array}$ \\
\hline \multirow[t]{6}{*}{2006} & Q5 & 0.978 & 0.4 & 0.98 & 1.8 & 0.26 & 2.2 & 0.04 & 0.7 & 0.06 & -2.0 & 0.04 \\
\hline & Q4 & 0.970 & 1.0 & 0.96 & 2.1 & 0.22 & 2.9 & 0.08 & -0.7 & 0.10 & 0.6 & 0.11 \\
\hline & Q3 & 0.948 & 1.5 & 0.92 & 0.7 & 0.15 & 1.8 & 0.09 & -0.1 & 0.20 & -0.9 & 0.16 \\
\hline & Q2 & 0.913 & 2.6 & 0.87 & -3.2 & 0.12 & 1.1 & 0.13 & 3.5 & 0.19 & 1.2 & 0.29 \\
\hline & Q1 & 0.828 & 6.6 & 0.73 & 4.2 & 0.09 & 2.0 & 0.24 & -5.4 & 0.16 & -0.3 & 0.39 \\
\hline & Avg & 0.927 & 2.9 & 0.89 & 3.4 & 0.17 & -1.1 & 0.12 & -1.2 & 0.14 & -3.3 & 0.20 \\
\hline \multirow[t]{6}{*}{2009} & Q5 & 0.951 & -0.1 & 0.95 & 1.3 & 0.29 & 2.1 & 0.06 & 4.5 & 0.04 & -4.6 & 0.04 \\
\hline & Q4 & 0.923 & 0.5 & 0.96 & 5.5 & 0.23 & 8.0 & 0.08 & 2.2 & 0.17 & -13.0 & 0.09 \\
\hline & Q3 & 0.873 & 0.9 & 0.93 & 13.2 & 0.16 & 5.8 & 0.11 & 11.7 & 0.16 & 7.7 & 0.19 \\
\hline & Q2 & 0.859 & 3.7 & 0.86 & 5.0 & 0.10 & 9.0 & 0.21 & -4.3 & 0.15 & 0.9 & 0.28 \\
\hline & Q1 & 0.782 & 4.8 & 0.75 & 12.9 & 0.05 & 8.6 & 0.23 & 5.6 & 0.13 & -0.9 & 0.38 \\
\hline & Avg & 0.878 & 2.6 & 0.89 & 9.6 & 0.17 & 4.0 & 0.14 & 2.7 & 0.13 & -3.7 & 0.20 \\
\hline
\end{tabular}

Note: for each sub-group, the first column indicates the difference in end of period employment rates from the (quintile) average, in percent. The second column (italics) gives the $\%$ of the quintile population in that sub-group. At least 30 observations per cell. Figures computed using sample weights 
Table 7 Average marginal effects from probit regressions, combinations of boom years (with default specification)

\begin{tabular}{|c|c|c|c|c|c|c|c|c|c|c|}
\hline Year & 2004-2007 & 2004-2006 & 2005-2007 & 2004-2007 & 2004-2006 & 2005-2007 & 2004-2007 & 2004-2006 & 2005-2007 & 2005-2007 \\
\hline \multirow[t]{2}{*}{ Q2 } & $0.070^{* * *}$ & $0.074^{* * *}$ & $0.060^{* * *}$ & $0.076^{* * *}$ & $0.072^{* * *}$ & $0.072^{* * *}$ & $0.077^{* * *}$ & $0.073^{* * *}$ & $0.072^{* * *}$ & $0.074^{* * *}$ \\
\hline & $(0.0087)$ & $(0.0096)$ & $(0.0106)$ & $(0.0101)$ & $(0.0113)$ & $(0.0121)$ & $(0.0101)$ & $(0.0113)$ & $(0.0121)$ & $(0.0120)$ \\
\hline \multirow[t]{2}{*}{ Q3 } & $0.098^{* * *}$ & $0.107^{* * *}$ & $0.095^{* * *}$ & $0.102^{* * *}$ & $0.102^{* * *}$ & $0.104^{* * *}$ & $0.103^{* * *}$ & $0.103^{* * *}$ & $0.105^{* * *}$ & $0.110^{* * *}$ \\
\hline & $(0.0079)$ & $(0.0079)$ & $(0.00944)$ & $(0.0106)$ & $(0.0104)$ & $(0.0125)$ & $(0.0106)$ & $(0.0104)$ & $(0.0124)$ & $(0.0119)$ \\
\hline \multirow[t]{2}{*}{ Q4 } & $0.118^{* * *}$ & $0.122^{* * *}$ & $0.120^{* * *}$ & $0.122^{* * *}$ & $0.115^{* * *}$ & $0.130^{* * *}$ & $0.123^{* * *}$ & $0.116^{* * *}$ & $0.131^{* * *}$ & $0.132^{* * *}$ \\
\hline & $(0.0066)$ & $(0.0073)$ & $(0.00706)$ & $(0.0089)$ & $(0.0100)$ & $(0.00952)$ & $(0.0091)$ & $(0.0100)$ & $(0.00979)$ & $(0.0096)$ \\
\hline \multirow[t]{2}{*}{ Q5 } & $0.129^{* * *}$ & $0.129 * * *$ & $0.124^{* * *}$ & $0.129^{* * *}$ & $0.120^{* * *}$ & $0.128^{* * *}$ & $0.129 * * *$ & $0.121^{* * *}$ & $0.128^{* * *}$ & $0.130^{* * *}$ \\
\hline & $(0.0056)$ & $(0.0065)$ & $(0.00647)$ & $(0.0087)$ & $(0.0098)$ & $(0.0103)$ & $(0.0089)$ & $(0.0099)$ & $(0.0107)$ & $(0.0101)$ \\
\hline Base controls & & & & $x$ & $x$ & $x$ & $x$ & $x$ & $x$ & $x$ \\
\hline Occupations & & & & & & & $x$ & $x$ & $x$ & \\
\hline Industries & & & & & & & & & & $x$ \\
\hline \multicolumn{11}{|l|}{ Tests, $p$ values } \\
\hline $\mathrm{Q} 2=\mathrm{Q} 3$ & 0.001 & 0.001 & 0.001 & 0.002 & 0.001 & 0.001 & 0.002 & 0.001 & 0.001 & 0.001 \\
\hline $\mathrm{Q} 2=\mathrm{Q} 4$ & 0.001 & 0.001 & 0.001 & 0.001 & 0.001 & 0.001 & 0.001 & 0.001 & 0.001 & 0.001 \\
\hline $\mathrm{Q} 2=\mathrm{Q} 5$ & 0.001 & 0.001 & 0.001 & 0.001 & 0.001 & 0.001 & 0.001 & 0.001 & 0.001 & 0.001 \\
\hline Education dummies $=0$ & & & & 0.845 & 0.983 & 0.803 & 0.704 & 0.988 & 0.791 & 0.244 \\
\hline Age dummies $=0$ & & & & 0.001 & 0.001 & 0.001 & 0.001 & 0.001 & 0.001 & 0.001 \\
\hline Kids dummies $=0$ & & & & 0.001 & 0.001 & 0.001 & 0.001 & 0.001 & 0.001 & 0.001 \\
\hline Occupations $=0$ & & & & & & & 0.172 & 0.134 & 0.283 & \\
\hline Industries $=0$ & & & & & & & & & & 0.008 \\
\hline Pseudo $R^{2}$ & 0.057 & 0.059 & 0.061 & 0.131 & 0.136 & 0.140 & 0.133 & 0.139 & 0.141 & 0.147 \\
\hline Observations & 16,963 & 13,020 & 12,688 & 16,736 & 12,841 & 12,521 & 16,730 & 12,836 & 12,508 & 12,495 \\
\hline
\end{tabular}

Note: quintile thresholds are year specific, i.e. computed for the wages of the population of each year. Information on industries is not available in 2004 . Top of the table: std errors in parentheses; ${ }^{* * *} p<0.01$ ${ }^{* *} p<0.05,{ }^{*} p<0.1$. Base controls: female dummy; share of time worked part-time in the last 12 months; education and age dummies; permanent contract dummy; reported years of work experience; poor health status dummy; partner dummy for women and for men; and number of children aged 0-1, aged 1-5 and aged 6 and over. See text and Section 6.1 in the Appendix for more details on the construction of variables. Tests on coefficients: $p$ values reported; $p$ values in italics indicate that the test cannot be rejected at the $10 \%$ significance level; small $p$ values were rounded up to 0.001 
Table 8 Average marginal effects from probit regressions on joint data for 2009 and 2010 (with default specification)

\begin{tabular}{|c|c|c|c|c|c|c|c|c|c|c|c|c|}
\hline Quintile thresholds & $\begin{array}{l}\text { Fixed at } 2009 \\
\text { levels }\end{array}$ & $\begin{array}{l}\text { Fixed at } 2008 \\
\text { levels }\end{array}$ & $\begin{array}{l}\text { Year } \\
\text { specific }\end{array}$ & $\begin{array}{l}\text { Fixed at } 2009 \\
\text { levels }\end{array}$ & $\begin{array}{l}\text { Fixed at } 2008 \\
\text { levels }\end{array}$ & $\begin{array}{l}\text { Year } \\
\text { specific }\end{array}$ & $\begin{array}{l}\text { Fixed at } 2009 \\
\text { levels }\end{array}$ & $\begin{array}{l}\text { Fixed at } 2008 \\
\text { levels }\end{array}$ & Year specific & $\begin{array}{l}\text { Fixed at } 2009 \\
\text { levels }\end{array}$ & $\begin{array}{l}\text { Fixed at } 2008 \\
\text { levels }\end{array}$ & $\begin{array}{l}\text { Year } \\
\text { specific }\end{array}$ \\
\hline \multirow[t]{2}{*}{ Q2 } & $0.064^{* * *}$ & $0.051^{* *}$ & $0.066^{* * *}$ & $0.125^{* * *}$ & $0.108^{* * *}$ & $0.130^{* * *}$ & $0.126^{* * *}$ & $0.109^{* * *}$ & $0.132^{* * *}$ & $0.123^{* * *}$ & $0.107^{* * *}$ & $0.128^{* * *}$ \\
\hline & $(0.0209)$ & $(0.0216)$ & $(0.0204)$ & $(0.0200)$ & $(0.0227)$ & $(0.0197)$ & $(0.0202)$ & $(0.0231)$ & $(0.0199)$ & $(0.0204)$ & $(0.0229)$ & $(0.0201)$ \\
\hline \multirow[t]{2}{*}{ Q3 } & $0.099^{* * *}$ & $0.093^{* * *}$ & $0.099^{* * *}$ & $0.177^{* * *}$ & $0.164^{* * *}$ & $0.177^{* * *}$ & $0.189^{* * *}$ & $0.177^{* * *}$ & $0.188^{* * *}$ & $0.186^{* * *}$ & $0.174^{* * *}$ & $0.185^{* * *}$ \\
\hline & $(0.0194)$ & $(0.0192)$ & $(0.0189)$ & $(0.0195)$ & $(0.0210)$ & $(0.0192)$ & $(0.0188)$ & $(0.0205)$ & $(0.0186)$ & $(0.0185)$ & $(0.0199)$ & $(0.0183)$ \\
\hline \multirow[t]{2}{*}{ Q4 } & $0.138^{* * *}$ & $0.133^{* * *}$ & $0.137^{* * *}$ & $0.211^{* * *}$ & $0.200^{* * *}$ & $0.206^{* * *}$ & $0.226^{* * *}$ & $0.214^{* * *}$ & $0.222^{* * *}$ & $0.208^{* * *}$ & $0.198^{* * *}$ & $0.203^{* * *}$ \\
\hline & $(0.0148)$ & $(0.0145)$ & $(0.0145)$ & $(0.0178)$ & $(0.0186)$ & $(0.0175)$ & $(0.0180)$ & $(0.0189)$ & $(0.0176)$ & $(0.0179)$ & $(0.0183)$ & $(0.0176)$ \\
\hline \multirow[t]{2}{*}{ Q5 } & $0.163^{* * *}$ & $0.156^{* * *}$ & $0.159^{* * *}$ & $0.223^{* * *}$ & $0.211^{* * *}$ & $0.216^{* * *}$ & $0.236^{* * *}$ & $0.226^{* * *}$ & $0.229^{* * *}$ & $0.214^{* * *}$ & $0.204^{* * *}$ & $0.208^{* * *}$ \\
\hline & $(0.0123)$ & $(0.0123)$ & $(0.0122)$ & $(0.0168)$ & $(0.0187)$ & $(0.0167)$ & $(0.0179)$ & $(0.0200)$ & $(0.0178)$ & $(0.0173)$ & $(0.0191)$ & $(0.0172)$ \\
\hline Base controls & & & & $x$ & $x$ & $x$ & $x$ & $x$ & $x$ & $x$ & $x$ & $x$ \\
\hline $\begin{array}{l}\text { Occupations/ } \\
\text { industries }\end{array}$ & & & & & & & Occupations & Occupations & Occupations & Industries & Industries & Industries \\
\hline \multicolumn{13}{|l|}{ Tests, $p$ values } \\
\hline $\mathrm{Q} 2=\mathrm{Q} 3$ & 0.001 & 0.001 & 0.001 & 0.001 & 0.001 & 0.001 & 0.001 & 0.001 & 0.001 & 0.001 & 0.001 & 0.001 \\
\hline $\mathrm{Q} 2=\mathrm{Q} 4$ & 0.085 & 0.047 & 0.094 & 0.001 & 0.001 & 0.001 & 0.001 & 0.001 & 0.001 & 0.001 & 0.001 & 0.001 \\
\hline $\mathrm{Q} 2=\mathrm{Q} 5$ & 0.001 & 0.001 & 0.001 & 0.001 & 0.001 & 0.001 & 0.001 & 0.001 & 0.001 & 0.001 & 0.001 & 0.001 \\
\hline $\begin{array}{l}\text { Education } \\
\text { dummies }=0\end{array}$ & & & & 0.001 & 0.001 & 0.001 & 0.001 & 0.001 & 0.001 & 0.101 & 0.099 & 0.070 \\
\hline Age dummies $=0$ & & & & 0.110 & 0.130 & 0.114 & 0.079 & 0.093 & 0.079 & 0.222 & 0.243 & 0.223 \\
\hline Kids dummies $=0$ & & & & 0.003 & 0.003 & 0.003 & 0.005 & 0.004 & 0.006 & 0.001 & 0.001 & 0.001 \\
\hline Occupations =0 & & & & & & & 0.001 & 0.001 & 0.001 & & & \\
\hline Industries $=0$ & & & & & & & & & & 0.001 & 0.001 & 0.001 \\
\hline Pseudo $R^{2}$ & 0.048 & 0.047 & 0.047 & 0.117 & 0.114 & 0.116 & 0.139 & 0.137 & 0.138 & 0.151 & 0.148 & 0.150 \\
\hline Observations & 6648 & 6648 & 6648 & 6604 & 6604 & 6604 & 6593 & 6593 & 6593 & 6588 & 6588 & 6588 \\
\hline
\end{tabular}

Note: Our results suggest that low-paid jobs were disproportionately affected during the crisis. To limit the possibility that sample selection influences the threshold values during the crisis, we considered three alternative scenarios: fixing the values of the thresholds (in real terms) to the values computed on the 2008 earnings distribution, on the 2009 earnings distributions and year-specific thresholds. The last of these alternatives was explored in response to the observation that many employees experienced nominal pay cuts during the crisis, e.g. Doris et al. (2015). Top of the table: std errors in parentheses; ${ }^{* * *} p<0.01,{ }^{* *} p<0.05,{ }^{*} p<0.1$. Base controls: female dummy; share of time worked part-time in the last 12 months; education and age dummies; permanent contract dummy; reported years of work experience; poor health status dummy; partner dummy for women and for men; and number of children aged $0-1$, aged 1-5 and aged 6 and over. See text and Section 6.1 in the Appendix for more details on the construction of variables. Tests on coefficients: $p$ values reported; $p$ values in italics indicate that the test cannot be rejected at the $10 \%$ significance level; small $p$ values were rounded up to 0.001 
Table 9 Average marginal effects from probit regressions - excluding employees who report having changed jobs in year prior to the interview

\begin{tabular}{|c|c|c|c|c|c|c|c|c|}
\hline Year & $\begin{array}{l}2005- \\
2007\end{array}$ & $\begin{array}{l}2009- \\
2010\end{array}$ & $\begin{array}{l}2005- \\
2007\end{array}$ & $\begin{array}{l}2009- \\
2010\end{array}$ & $\begin{array}{l}2005- \\
2007\end{array}$ & $\begin{array}{l}2009- \\
2010\end{array}$ & $\begin{array}{l}2005- \\
2007\end{array}$ & $\begin{array}{l}2009- \\
2010\end{array}$ \\
\hline \multirow[t]{2}{*}{ Q2 } & $0.057^{* * *}$ & $0.063^{* * *}$ & $0.062^{* * *}$ & $0.131^{* * *}$ & $0.063^{* * *}$ & $0.132^{* * *}$ & $0.064^{* * *}$ & $0.127^{* * *}$ \\
\hline & $(0.0116)$ & $(0.0220)$ & $(0.0131)$ & $(0.0210)$ & $(0.0131)$ & $(0.0212)$ & $(0.0132)$ & $(0.0215)$ \\
\hline \multirow[t]{2}{*}{ Q3 } & $0.098^{* * *}$ & $0.105^{* * *}$ & $0.100^{* * *}$ & $0.187^{* * *}$ & $0.101^{* * *}$ & $0.200^{* * *}$ & $0.103^{* * *}$ & $0.195^{* * *}$ \\
\hline & $(0.0101)$ & $(0.0203)$ & $(0.0134)$ & $(0.0203)$ & $(0.0132)$ & $(0.0197)$ & $(0.0129)$ & (0.0194) \\
\hline \multirow[t]{2}{*}{ Q4 } & $0.126^{* * *}$ & $0.149^{* * *}$ & $0.127^{* * *}$ & $0.229 * * *$ & $0.128^{* * *}$ & $0.245^{* * *}$ & $0.129^{* * *}$ & $0.225^{* * *}$ \\
\hline & $(0.00734)$ & $(0.0150)$ & $(0.0101)$ & $(0.0180)$ & $(0.0104)$ & $(0.0182)$ & $(0.0100)$ & $(0.0180)$ \\
\hline \multirow[t]{2}{*}{ Q5 } & $0.131^{* * *}$ & $0.172^{* * *}$ & $0.127^{* * *}$ & $0.235^{* * *}$ & $0.126^{* * *}$ & $0.250^{* * *}$ & $0.127^{* * *}$ & $0.224^{* * *}$ \\
\hline & $(0.00672)$ & $(0.0126)$ & $(0.0108)$ & $(0.0176)$ & $(0.0112)$ & $(0.0188)$ & $(0.0107)$ & $(0.0184)$ \\
\hline Base controls & & & $x$ & $x$ & $x$ & $x$ & $x$ & $x$ \\
\hline Occupations & & & & & $x$ & $x$ & & \\
\hline Industries & & & & & & & $x$ & $x$ \\
\hline \multicolumn{9}{|l|}{ Tests, $p$ values } \\
\hline $\mathrm{Q} 2=\mathrm{Q} 3$ & 0.001 & 0.051 & 0.002 & 0.001 & 0.002 & 0.001 & 0.001 & 0.001 \\
\hline $\mathrm{Q} 2=\mathrm{Q} 4$ & 0.001 & 0.001 & 0.001 & 0.001 & 0.001 & 0.001 & 0.001 & 0.001 \\
\hline $\mathrm{Q} 2=\mathrm{Q} 5$ & 0.001 & 0.001 & 0.001 & 0.001 & 0.001 & 0.001 & 0.001 & 0.001 \\
\hline $\begin{array}{l}\text { Education } \\
\text { dummies }=0\end{array}$ & & & 0.633 & 0.001 & 0.650 & 0.001 & 0.194 & 0.077 \\
\hline Age dummies $=0$ & & & 0.001 & 0.033 & 0.001 & 0.027 & 0.001 & 0.081 \\
\hline Kids dummies $=0$ & & & 0.001 & 0.001 & 0.001 & 0.007 & 0.001 & 0.002 \\
\hline Occupations $=0$ & & & & & 0.216 & 0.001 & & \\
\hline Industries $=0$ & & & & & & & 0.012 & 0.001 \\
\hline Pseudo $R^{2}$ & 0.065 & 0.053 & 0.143 & 0.115 & 0.152 & 0.152 & 0.157 & 0.165 \\
\hline Observations & 11,805 & 6394 & 11,664 & 6355 & 11,652 & 6345 & 11,646 & 6339 \\
\hline
\end{tabular}

Note: default specification, see Table 3. Quintile thresholds for 2005-2007 are year specific. Quintile thresholds in the 2009-2010 sample are fixed at 2009 values (in real terms). Top of the table: std errors in parentheses; ${ }^{* * *} p<0.01$, ${ }^{* *} p<0.05,{ }^{*} p<0.1$. Base controls: female dummy; share of time worked part-time in the last 12 months; education and age dummies; permanent contract dummy; reported years of work experience; poor health status dummy; partner dummy for women and for men; and number of children aged $0-1$, aged 1-5 and aged 6 and over. See text and Section 6.1 in the Appendix for more details on the construction of variables. Tests on coefficients: $p$ values reported; $p$ values in italics indicate that the test cannot be rejected at the $10 \%$ significance level; small $p$ values were rounded up to 0.001 
Table 10 Average marginal effects from probit regressions, extended employee sample (with default specification)

\begin{tabular}{|c|c|c|c|c|c|c|c|c|}
\hline Year & $\begin{array}{l}2005- \\
2007\end{array}$ & $\begin{array}{l}2009- \\
2010\end{array}$ & $\begin{array}{l}2005- \\
2007\end{array}$ & $\begin{array}{l}2009- \\
2010\end{array}$ & $\begin{array}{l}2005- \\
2007\end{array}$ & $\begin{array}{l}2009- \\
2010\end{array}$ & $\begin{array}{l}2005- \\
2007\end{array}$ & $\begin{array}{l}2009- \\
2010\end{array}$ \\
\hline \multirow[t]{2}{*}{ Q2 } & $0.063^{* * *}$ & $0.071^{* * *}$ & $0.072^{* * *}$ & $0.124^{* * *}$ & $0.072^{* * *}$ & $0.125^{* * *}$ & $0.073^{* * *}$ & $0.123^{* * *}$ \\
\hline & $(0.0107)$ & $(0.0208)$ & $(0.0122)$ & $(0.0202)$ & $(0.0122)$ & $(0.0205)$ & $(0.0122)$ & $(0.0205)$ \\
\hline \multirow[t]{2}{*}{ Q3 } & $0.098^{* * *}$ & $0.101^{* * *}$ & $0.105^{* * *}$ & $0.169 * * *$ & $0.106^{* * *}$ & $0.181^{* * *}$ & $0.109^{* * *}$ & $0.179^{* * *}$ \\
\hline & $(0.00951)$ & $(0.0195)$ & $(0.0126)$ & $(0.0205)$ & $(0.0125)$ & $(0.0198)$ & $(0.0121)$ & $(0.0194)$ \\
\hline \multirow[t]{2}{*}{ Q4 } & $0.125^{* * *}$ & $0.142^{* * *}$ & $0.132^{* * *}$ & $0.206^{* * *}$ & $0.133^{* * *}$ & $0.221^{* * *}$ & $0.135^{* * *}$ & $0.205^{* * *}$ \\
\hline & $(0.00704)$ & $(0.0148)$ & $(0.00950)$ & $(0.0185)$ & (0.00978) & $(0.0187)$ & $(0.00944)$ & $(0.0185)$ \\
\hline \multirow[t]{2}{*}{ Q5 } & $0.128^{* * *}$ & $0.167^{* * *}$ & $0.130^{* * *}$ & $0.219^{* * *}$ & $0.130^{* * *}$ & $0.232^{* * *}$ & $0.131^{* * *}$ & $0.211^{* * *}$ \\
\hline & $(0.00658)$ & $(0.0124)$ & $(0.0104)$ & $(0.0179)$ & $(0.0108)$ & $(0.0192)$ & $(0.0103)$ & $(0.0185)$ \\
\hline Base controls & & & $x$ & $x$ & $x$ & $x$ & $x$ & $x$ \\
\hline Occupations & & & & & $x$ & $x$ & & \\
\hline Industries & & & & & & & $x$ & $x$ \\
\hline \multicolumn{9}{|l|}{ Tests, $p$ values } \\
\hline $\mathrm{Q} 2=\mathrm{Q} 3$ & 0.001 & 0.130 & 0.002 & 0.001 & 0.002 & 0.001 & 0.001 & 0.001 \\
\hline $\mathrm{Q} 2=\mathrm{Q} 4$ & 0.001 & 0.001 & 0.001 & 0.001 & 0.001 & 0.001 & 0.001 & 0.001 \\
\hline $\mathrm{Q} 2=\mathrm{Q} 5$ & 0.001 & 0.001 & 0.001 & 0.001 & 0.001 & 0.001 & 0.001 & 0.001 \\
\hline $\begin{array}{l}\text { Education } \\
\text { dummies }=0\end{array}$ & & & 0.791 & 0.983 & 0.800 & 0.001 & 0.247 & 0.230 \\
\hline Age dummies $=0$ & & & 0.001 & 0.117 & 0.001 & 0.083 & 0.001 & 0.223 \\
\hline Kids dummies $=0$ & & & 0.001 & 0.001 & 0.001 & 0.013 & 0.001 & 0.004 \\
\hline Occupations $=0$ & & & & & 0.290 & 0.001 & & \\
\hline Industries $=0$ & & & & & & & 0.011 & 0.001 \\
\hline Pseudo $R^{2}$ & 0.062 & 0.048 & 0.143 & 0.115 & 0.144 & 0.135 & 0.150 & 0.147 \\
\hline Observations & 12,814 & 6695 & 12,647 & 6651 & 12,634 & 6640 & 12,626 & 6635 \\
\hline
\end{tabular}

Note: The "extended" sample of employee includes people who reported working as an employee 12 and/or 11 months prior to the month of the interview. Quintile thresholds for 2005-2007 are year specific. Quintile thresholds fixed at 2009 values (in real terms) in the 2009-2010 sample. Top of the table: std errors in parentheses; ${ }^{* * *} p<0.01,{ }^{* *} p<0.05,{ }^{*} p<0.1$. Base controls: female dummy; share of time worked part-time in the last 12 months; education and age dummies; permanent contract dummy; reported years of work experience; poor health status dummy; partner dummy for women and for men; and number of children aged 0-1, aged 1-5 and aged 6 and over. See text and Section 6.1 in the Appendix for more details on the construction of variables. Tests on coefficients: $p$ values reported; $p$ values in italics indicate that the test cannot be rejected at the $10 \%$ significance level; small $p$ values were rounded up to 0.001 
Table 11 Average marginal effects from probit regressions, with extended set of explanatory variables

\begin{tabular}{|c|c|c|c|c|c|c|c|c|}
\hline Year & $\begin{array}{l}2005- \\
2007\end{array}$ & $\begin{array}{l}2009- \\
2010\end{array}$ & $\begin{array}{l}2005- \\
2007\end{array}$ & $\begin{array}{l}2009- \\
2010\end{array}$ & $\begin{array}{l}2005- \\
2007\end{array}$ & $\begin{array}{l}2009- \\
2010\end{array}$ & $\begin{array}{l}2005- \\
2007\end{array}$ & $\begin{array}{l}2009- \\
2010\end{array}$ \\
\hline \multirow[t]{2}{*}{$\overline{\mathrm{Q} 2}$} & $0.060^{* * *}$ & $0.064^{* * *}$ & $0.070^{* * *}$ & $0.127^{* * *}$ & $0.070^{* * *}$ & $0.128^{* * *}$ & $0.071^{* * *}$ & $0.125^{* * *}$ \\
\hline & $(0.0106)$ & (0.0209) & $(0.0121)$ & $(0.0200)$ & $(0.0121)$ & $(0.0202)$ & $(0.0121)$ & $(0.0202)$ \\
\hline \multirow[t]{2}{*}{ Q3 } & $0.095^{* * *}$ & $0.099 * * *$ & $0.100^{* * *}$ & $0.178^{* * *}$ & $0.102^{* * *}$ & $0.192^{* * *}$ & $0.105^{* * *}$ & $0.191^{* * *}$ \\
\hline & $(0.00944)$ & $(0.0194)$ & $(0.0126)$ & $(0.0200)$ & $(0.0124)$ & $(0.0191)$ & $(0.0120)$ & $(0.0186)$ \\
\hline \multirow[t]{2}{*}{ Q4 } & $0.120^{* * *}$ & $0.138^{* * *}$ & $0.126^{* * *}$ & $0.213^{* * *}$ & $0.127^{* * *}$ & $0.231^{* * *}$ & $0.129^{* * *}$ & $0.215^{* * *}$ \\
\hline & $(0.00706)$ & $(0.0148)$ & $(0.00962)$ & $(0.0183)$ & $(0.00980)$ & $(0.0183)$ & $(0.00950)$ & $(0.0181)$ \\
\hline \multirow[t]{2}{*}{ Q5 } & $0.124^{* * *}$ & $0.163^{* * *}$ & $0.123^{* * *}$ & $0.226^{* * *}$ & $0.124^{* * *}$ & $0.245^{* * *}$ & $0.125^{* * *}$ & $0.225^{* * *}$ \\
\hline & $(0.00647)$ & $(0.0123)$ & $(0.0106)$ & $(0.0177)$ & $(0.0109)$ & $(0.0186)$ & $(0.0105)$ & $(0.0182)$ \\
\hline Extended controls & & & $x$ & $x$ & $x$ & $x$ & $x$ & $x$ \\
\hline $\begin{array}{l}\text { Occupation } \\
\text { dummies }\end{array}$ & & & & & $x$ & $x$ & & \\
\hline Industry dummies & & & & & & & $x$ & $x$ \\
\hline \multicolumn{9}{|l|}{ Tests on coefficients } \\
\hline $\mathrm{Q} 2=\mathrm{Q} 3$ & 0.001 & 0.001 & 0.001 & 0.001 & 0.001 & 0.001 & 0.001 & 0.001 \\
\hline $\mathrm{Q} 2=\mathrm{Q} 4$ & 0.001 & 0.085 & 0.002 & 0.001 & 0.001 & 0.001 & 0.001 & 0.001 \\
\hline $\mathrm{Q} 2=\mathrm{Q} 5$ & 0.001 & 0.001 & 0.001 & 0.001 & 0.001 & 0.001 & 0.001 & 0.001 \\
\hline $\begin{array}{l}\text { Education } \\
\text { dummies }=0\end{array}$ & & & 0.810 & 0.001 & 0.796 & 0.001 & 0.292 & 0.096 \\
\hline Age dummies $=0$ & & & 0.001 & 0.053 & 0.001 & 0.043 & 0.001 & 0.120 \\
\hline Kids controls $=0$ & & & 0.001 & 0.008 & 0.001 & 0.004 & 0.001 & 0.001 \\
\hline $\begin{array}{l}\text { Occupation } \\
\text { dummies }=0\end{array}$ & & & & & 0.199 & 0.001 & & \\
\hline Industry dummies $=0$ & & & & & & & 0.012 & 0.001 \\
\hline Pseudo $R^{2}$ & 0.061 & 0.048 & 0.143 & 0.120 & 0.144 & 0.142 & 0.150 & 0.153 \\
\hline Observations & 12,688 & 6648 & 12,520 & 6594 & 12,507 & 6583 & 12,500 & 6578 \\
\hline
\end{tabular}

Note: quintile thresholds for 2005-2007 are year specific. Quintile thresholds for 2009-2010 fixed at 2009 values (in real terms). Top of the table: std errors in parentheses; ${ }^{* * *} p<0.01,{ }^{* *} p<0.05,{ }^{*} p<0.1$. Extended controls include base controls plus regional dummies, dummy if respondent has a say in the promotion of others, dummy if respondent work(ed) in a large company. Base controls: female dummy; share of time worked part-time in the last 12 months; education and age dummies; permanent contract dummy; reported years of work experience; poor health status dummy; partner dummy for women and for men; and number of children aged $0-1$, aged 1-5 and aged 6 and over. Tests on coefficients: $p$ values reported; values in italics indicate that the test cannot be rejected at the $10 \%$ significance level; small $p$ values were rounded up to 0.001 


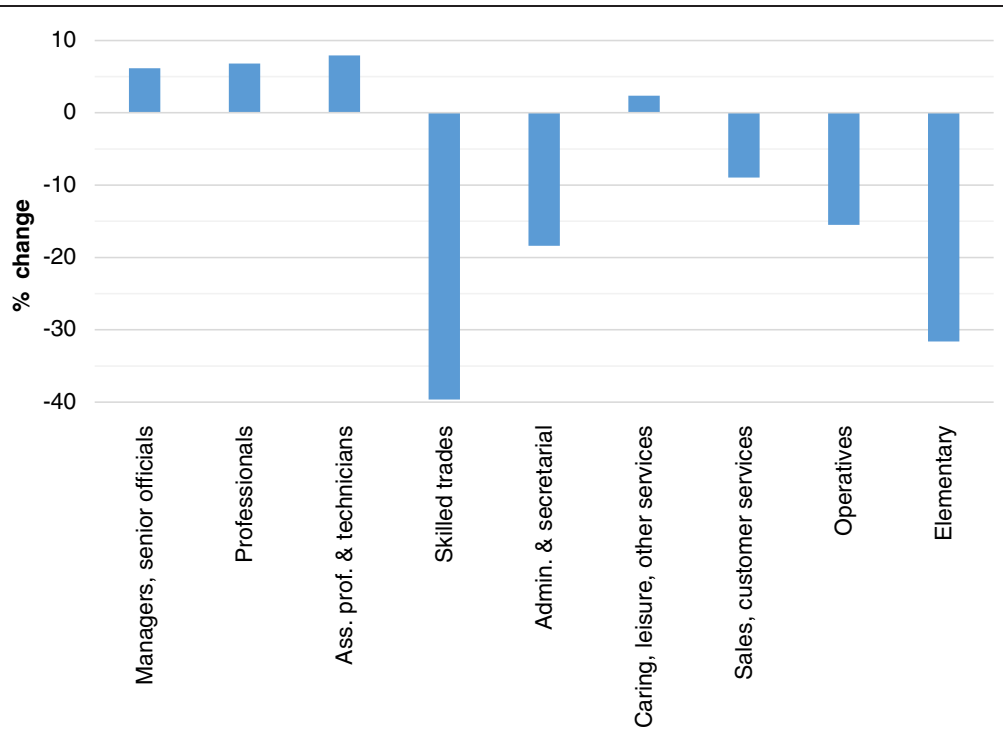

Fig. 1 Percent change in the number of people at work in Ireland between 2007 and 2012, by occupations

\section{Competing interests}

The IZA Journal of European Labor Studies is committed to the IZA Guiding Principles of Research Integrity. The authors declare that they have observed these principles.

\section{Acknowledgements}

The authors are very grateful for the assistance and advice provided by Bertrand Maître (Economic and Social Research Institute). Sarah Voitchovsky is grateful to the Swiss National Science Foundation for the financial support. We would also like to thank the anonymous referee and the editor for the useful remarks.

Responsible editor: Alan Barrett

\section{Author details}

${ }^{1}$ Institute for New Economic Thinking and Department of Social Policy and Intervention, Eagle House, University of Oxford, Walton Well Road, Oxford OX2 6ED, UK. ${ }^{2}$ Melbourne Institute of Applied Economics of Social Research, University of Melbourne, Level 5, Business and Economics Building, 111 Barry Street, Melbourne, Victoria 3010, Australia.

Received: 14 September 2015 Accepted: 22 February 2016

\section{Published online: 13 April 2016}

\section{References}

Autor, D (2010) The polarization of job opportunities in the U.S. labor market, implications for employment and earnings. Paper released by The Center for American Progress and The Hamilton Project, Washington DC.

Bartus T (2005) Estimation of marginal effects using margeff. Stata J 5(3):309-329

Doris A, O'Neill D, Sweetman O (2015) Wage flexibility and the great recession: the response of the Irish labour market. IZA J Eur Lab Stud 4(18):1-24.

Elsby M, Hobijn B, Sabin A (2010) The labor market in the Great Recession., NBER Woking Paper, WP no 15979

Fernandez-Macias E (2012) Job polarization in Europe? Changes in the employment structure and job quality, 1995-2007. Work Occup 39(2):157-182

Foote C, Ryan R (2015) Labor market polarization over the business cycle., NBER Working Paper, WP no 21030

Goldthorpe J, McKnight A (2004) The economic basis of social class, Centre for Analysis of Social Exclusion, London School of Economics, CASE WP 80

Goos M, Manning A, Salomons A (2009) The polarization of the European labor market. Am Econ Rev 99(2):58-63 Kelly E, McGuinness S (2015) Impact of the Great Recession on unemployed and NEET individuals' labour market transitions in Ireland, Economic Systems, 2015

Margo R (1992) Employment and unemployment in the 1930s., NBER Working Paper Series, WP no 4174

McGinnity F, Russell H, Watson D, Kingston G, Kelly E (2014) Winners and losers? The equality impact of the Great Recession, Equality Research Series, Equality Authority and the Economic and Social Research Institute, Dublin

Mühlau P (2014) Middle class squeeze? Social class and perceived financial hardship in Ireland, 2002-2012. Econ Soc Rev 45(4):485-509

O'Farrell R (2013) The polarisation of working hours in Ireland., NERI Working Paper Series, NERI WP 2013/09

Savage M, Callan T, Nolan B, Colgan B (2015) The Great Recession, austerity and inequality: evidence from Ireland., ESRI Working Paper no 499

Wilkins R, Wooden M (2011) Gender differences in rates of job dismissal: why are men more likely to lose their jobs?., IZA DP no 6225 